\title{
IETS OVER DE PAPOEWAS VAN DE GEELVINKSBAAI.
}

OPMERKINGEN NAAR AANLEIDING VAN UHLE'S, ,HOLZ- UND BAMBUS-GERAETHE AUS NORD WEST NEU GUINEA".

DOOR

Dr. G. A. WILK EN.

Onder den titel "Holz- und Bambus-Geräthe aus Nord West Neu Guinea mit besonderer Berücksichtigung der Ornamentik" verscheen, als zesde deel van de "Publicationen aus dem Königlichen Ethnographischen Museum zu Dresden", een hoogst belangrijk werk van Dr. Max Uhle, Assistent bij genoemd museum. Op een zevental goed uitgevoerde platen vinden wij verscheidene voorwerpen van hout of bamboe afgebeeld, afkomstig van de Geelvinksbaai, en grootendeels door Dr. Meyer, tijdens zijn verblijf aldaar in 1873, bijeengebracht. Bij deze platen behoort een tekst van dertien bladzijden, groot folio. Deze tekst bevat eerst eene inleiding, waarop een hoofdstuk volgt waarin de afgebeelde voorwerpen uitvoerig worden besproken. Achtereenvolgens krijgen wij de volgende paragrafen: 1. Schiffschnabelverzierungen, 2. Ahnenbilder, 3. Amulete, 4. Löffel, 5. Behälter von Bambus, 6. Ornamentirte Pfeile, 7. Nackenschemel, 8. Schwimmer für Schildkrötenfang, 9. Beilstiel, 10. Armstütze aus einem Boot, 11. Zeugschlägel , 12. Töpferschlägel, 13. Pokal. Bijna in elke paragraaf vindt men talrijke verwijzingen naar bestaande af beeldingen of beschrijvingen van analoge voorwerpen, af komstig zoowel van NieuwGuinea als van andere deelen van den Indischen Archipel. Wij kunnen niet anders dan Dr. Uhle lof toezwaaien voor de wijze, waarop hij zich van dit gedeelte zijner taak gekweten heeft. Met groote zorg heeft hij tal van verspreide gegevens bijeengebracht, en daarbij onder anderen ook eene bekendheid getoond met onze literatuur over Indië, zooals wij die zelden bij eenen vreemdeling hebben ontmoet. $\mathrm{Na}$ de beschrijving der voorwerpen, wordt in een uitvoerig hoofdstuk "die Ornamentik der Gegenstände im Zusammenhange besprochen". Dr. Uhle tracht daarbij met veel scherpzinnigheid de schijnbaar 
verwarde en willekeurige ornamenten te ontleden, de motieven daarvan op te sporen, en aan te toonen, dat deze grootendeels bestaan uit nabootsingen van dieren, dat de Papoesche ornamentiek dus is een dierornamentiek, hoewel ook sporen van plantenornamentiek aan te wijzen zijn.

Ziehier kortelijk den inhoud van Uhle's werk. Hiermede is echter niet alles gezegd. Op het hoofdstuk over de ornamentiek volgt namelijk nog een ander, getiteld "Resultate der Untersuchung ", dat speciaal gewijd is aan de beantwoording der vraag, door den schrijver reeds in de inleiding gesteld, of de Papoewas van de kusten der Geelvinksbaai "sich zum Theil von einem reinen Naturzustand aus durch eigene Initiative oder durch äussere Beeinflussung auf eine höhere Stufe erhoben haben, oder ob sie in diesen Naturzustand zurückgefallen sind" (bladz. 1). Dr. Uhle wil deze vraag in den tweeden zin beantwoord hebben. "Die für die physische Natur meist angenommene und damit wohl auch für die culturelle Seite der Existenz stillschweigend vorausgesetzte Reinheit dieser Papuas besteht wenigstens für die culturelle Seite ihrer Existenz nicht, wenn auch eine wirkungsvolle physische Mischung nicht nothwendig damit verbunden gewesen sein muss" (blz. 13). Uhle meent dan ook, dat "die Papuas der Küsten der Geelvinkbai mittels äusserer Beeinflussung in einen höheren Zustand erhoben worden sind" (t. a. p.). Volgens hem, "ist die Beeinflussung vom Ostindischen Archipel aus dirigirt. Theils weisen die Beziehungen auf den Ostindischen Archipel im Allgemeinen zurück (Ahnencult, Thierverwandtschaft, Thierbilder als Ursache des Thierstils), theils auf einzelne südliche Theile desselben (vergleiche die Uebereinstimmungen bei den Ahnenbildern), viele sind offenbar von Halmahera ausgegangen oder weisen wenigstens auf dieses hauptsächlich zurück. Vergleiche die Spiralcaunelirung, die durchbrochenen Schnitzereien, einzelne Musterungen der Bambusgefässe, die Krokodile in den Ahnenhäuschen, Uebereinstimmungen in Geräthen u. a. Die Stabamulete finden jenseits Halmahera (Mindanao) ihre Parallele” (t. a. p.). Men ziet dat Dr. Uhle zijne conclusie hoofdzakelijk baseert op argumenten, ontleend aan de overeenkomst tusschen de voorwerpen en de ornamentiek van Nieuw-Guinea aan den eenen en die van den Indischen Archipel aan den anderen kant. Doch er is meer. "Eine bedeutende Entlehnung aus, oder, im Sinne der Verfasser gesprochen, Mischung mit dem Malayischen ist auch für die Sprache der Mafōr schon in einem kurzen Aufsatz der Hrrn. G. v. d. Gabelentz und A. B. Meyer nach- 
gewiesen worden. Mit diesem sprachlichen Resultat ist das aus der Vergleichung der Culturen gewonnene in Uebereinstimmung" (t. a. p.). Tegen dit laatste wenschen wij reeds dadelijk het een en ander op te merken.

Het door Dr. Uhle bedoelde opstel van de Heeren Meyer en Von der Gabelentz draagt den titel "Einiges über das Verhältniss des Mafoor zum Malayischen" en is opgenomen in het linguistisch gedeelte der "Bijdragen tot de Taal- Land- en Volkenkunde van Nederlandsch Indië", als feestgave door het Koninklijk Instituut aangeboden aan het zesde Orientalisten Congres, gehouden te Leiden in 1883. Het bevreemdt ons dat Dr. Uhle zich alleen op dit stuk beroepen heeft. Is het hem dan niet bekend, dat bij dezelfde gelegenheid dat onderwerp grondiger en uitvoeriger door een anderen geleerde, dien iedereen zeker als den meester der Maleisch-Polynesische taalvergelijking erkennen zal, door Prof. Kern behandeld is? In de publicaties van het congres kan Dr. Uhle diens doorwrochte verhandeling vinden '. Het Mafoorsch of Noefoorsch wordt daarin niet alleen vergeleken met het Maleisch, doch nagenoeg met alle bekende talen van den Indischen Archipel, Polynesië en Melanesië. Dit hebben de Heeren Meyer en Von der Gabelentz niet gedaan: daardoor is hun werk oppervlakkiger, zijn de resultaten hunner nasporingen minder zeker, zoekt men tevergeefs bij hen naar de etymologie van de meest belangrijke woorden 2 , terwijl men daartegenover dikwijls de zonderlingste vergelijkingen ontmoet, gelijk bij voorbeeld van het Mafoorsche bruěr met het Maleische utara, zij het dat voorzichtigheidshalve daarbij een vraagteeken gesteld is ${ }^{3}$. Had Dr. Uhle de verhandeling van

1 Kern, Over de verhouding van het Mafoorsch tot de Maleisch-Polynesische talen, Actes du sixième congrès international des Orientalistes, dl. IV, blz. 215 vv.

2 Zoo bij voorbeeld van het woord snun $=$ mensch, man. Hoe leerzaam de etymologie van dit woord is voor de Maleisch-Polynesische taalvergelijking, kan men zien bij Kern, O. c., bls. 263, i. v.

s Het woord bruer of brar is, gelijk wij bij Kern, O. c., blz. 233, i. v., leeren, samengesteld uit het voorzetsel be en ruer of râr = Kawi hoar, Jav. lor $=$ Noorden. Gelijk men weet, is dit woord slechts eene varieteit van Kawi lod, Mal. laut, Bul. lauer, enz. = zee. Voor dit gebruik van het woord voor zee in de beteekenis van eene windstreek, zie men onze aankondiging van Riedel's "De sluik- en kroesharige rassen tusschen Selebes en Papoea", opgenomen in "De Indische Gids", jaarg. 1886 , dl. II, blz. 1598 vlg. Aan de daar gegeven voorbeelden kan nog toegevoegd worden het Formosaansche raur of raos $=$ Westen (Zie: Kern, Handschriften uit het eiland Formosa, Verslagen en Mededeelingen der Koninklijke Akademie van Wetenschappen, Afd. Letterkunde, 3e reeks, dl. III, blz. 367). 
Prof. Kern gelezen, dan zou hij gezien hebben, dat, ten aanzien van de taal, van eene "Entlehnung" in den door hem bedoelden zin geen sprake is. Natuurlijk dat het Mafoorsch vreemde woorden overgenomen heeft. Welke taal heeft niet hetzelfde gedaan? Doch men herkent deze overgenomen woorden, waaronder ettelijke die de Maleiers-zelven van Indiërs, Arabieren, Perzen en Europeanen ontvangen hebben, op den eersten blik, en meestal daaraan, dat zij den eindklinker ongeschonden bewaard hebben, hetgeen tegen de klankwetten van het Mafoorsch indruischt. Zij zijn dus niet alleen klaarblijkelijk vreemdelingen, maar ook in betrekkelijk laten tijd ingedrongen 4. Ten aanzien van verreweg de meeste woorden echter (en daartoe behooren de allereenvoudigste begrippen, zooals de termen voor eten, drinken, slapen, visch, vogel, vuur, de tel- en voornaamwoorden) moet de overeenkomst tusschen het Mafoorsch en de talen van Indo- en Polynesië niet uit overname of ontleening bij onderling verkeer verklaard worden, maar uit eene oorspronkelijke verwantschap, uit het feit dat die woorden van den aanvang af aan de Malayo-Polynesiërs en de Papoewas gemeen moeten zijn geweest. Het groote verschil, dat er in anthropologisch opzicht tusschen deze volken bestaat, doet zeker die conclusie eenigszins gewaagd schijnen. Prof. Kern heeft echter zijn vergelijkend onderzoek niet alleen beperkt tot het Mafoorsch, doch zulks ook uitgestrekt over meer Papoesche talen uit ver van elkander gelegen streken van Nieuw-Guinea en bij allen dezelfde overeenkomst met het Maleisch-Polynesisch aangetroffen. Zij, zegt nu de Hoogleeraar terecht, die ontkennen willen dat de Papoesche talen met de Maleisch-Polynesische verwant zijn, moeten dus tevens aannemen, dat de Papoewas hunne woorden voor eten en drinken, voor vuur en water, en dergelijke allereenvoudigste begrippen meer, ontleend hebben na onderlinge afspraak, want anders zou er niet zulk eene eenstemmigheid onder de dialecten heerschen 5. Dit is zeker zeer onwaarschijnlijk, en zoo ligt het meer voor de hand, om de overeenkomst tusschen het Papoesch en het Indonesisch als een gevolg van raseenheid te beschouwen. Het argument, dat Dr. Uhle ten gunste zijner stelling aan de taal ontleenen wil, vervalt daarmede vanzelf. Wil men van de overeenkomst tusschen de cultuur der Papoewas van de Geelvinksbaai en die der stammen van Indonesië, eene overeenkomst welke in vele opzichten

4 Kern, O. c., blz. 219.

5 Kern, 0. e., blz. 240. 
werkelijk bestaat, volstrekt eene verklaring hebben (hetgeen onzes inziens niet, althans niet altijd, noodig is, daar het veelal zaken betreft, die niet specifiek Indonesisch of Papoesch, doch algemeen menschelijk zijn), dan zoeke men die, evenals dit bij de taal gedaan moet worden, in het feit dat die volken oorspronkelijk één zijn geweest, genealogisch dus verwant zijn. Natuurlijk willen wij daarmede niet ontkennen, dat de bewoners van de Geelvinksbaai, bij hun verkeer met de Maleiers, het een en ander van dezen kunnen hebben overgenomen, gelijk zij immers op die wijze ook hunne taal, zooals wij gezien hebben, met ettelijke woorden verrijkt hebben.

Het is ons doel niet, hier eene aankondiging of critiek in den gewonen zin des woords van het werk van Dr. Uhle te geven. Liever nemen wij, zij het dan ook door omstandigheden later dan wij gewenscht hadden, uit het verschijnen van het boek aanleiding, om een paar van de voornaamste zaken, die er in behandeld worden, een weinig op te helderen, en verder eenige mededeelingen te doen, die eensdeels de meeningen en beschouwingen van den schrijver staven, anderendeels dienen moeten ter bestrijding van hetgeen ons daarin, en dit geldt vooral de zooeven bedoelde hoofdvraag omtrent de al of niet oorspronkelijkheid van de cultuur der Papoewas, minder juist voorkomt.

Onder de door Dr. Uhle afgebeelde voorwerpen bevinden zich ook eenige korwar's of korowâr's, beelden van de afgestorvenen. Dezen komen voor op Plaat III, terwijl op blz. 3 vlg. de beschrijving daarvan gegeven wordt. Het gebruik om beelden van de afgestorvenen te maken, ontmoet men bij tal van volken in den Indischen Archipel, gelijk wij elders uitvoerig hebben aangetoond ${ }^{6}$. Deze beelden worden gebruikt bij de zielenvereering. Men heeft daaromtrent, gelijk bekend kan zijn, twee voorstellingen: de ziel wordt namelijk geacht òf zich duurzaam in het beeld te bevinden, òf tijdelijk daarin te komen, wanneer zij uit het schimmenrijk of het zielenland wordt geroepen, om geraadpleegd te worden dan wel van de offers te genieten, die men haar brengen wil 7. In het eerste geval neemt men ook het bestaan van een zielenland aan, doch de ziel, die hier verblijf houdt, is eene

- Zie onze verhandeling: Het animisme bij de volken van den Indischen Archipel, blz. 164 vv.

7 De eerste voorstelling vindt men onder anderen bij de Niasers (Animisme, blz. 170-171), de tweede in de Molukken bij de bewoners van Ceram, Aroe, Kei, Timorlaoet en de Zuidoostereilanden (Animisme, blz. 168-169). 
andere dan die, welke in het beeld aanwezig wordt gedacht, een uitvloeisel van het algemeen verspreide geloof, dat de mensch meerdere zielen heeft. Welke van beide voorstellingen nu geldt bij de Papoewas van de Geolvinksbaai? Hieromtrent kan geen twijfel bestaan. Wij vinden toch uitdrukkelijk vermeld, dat als de korwar gereed is, de ziel daarin gebracht wordt. "Man stellt sich vor", aldus deelt Dr. Meyer mede, "dass der Geist noch in der Nähe umherirrt, und es gilt nun, ihn von überall zu vertreiben, damit er in das Bild gehe. Gegen Abend beginnt man auf ein gegebenes Zeichen in allen Häusern zu gleicher Zeit einen Höllenlärm zu vollführen. Man schlägt auf die Trommeln, man schreit und klopft, kurz man macht so viel Lärm als möglich. Das wiederholt sich mehre Abende hintereinander und dabei hält einer der Zauberer den Korwar unter Gesichterschneiden und Geschrei in der Hand, schüttelt das Holzbild und fällt plötzlich nieder, ein Zeichen, dass der Geist eingefahren ist" 8. Niet minder duidelijk is de mededeeling van Von Rosenberg. "Hat man den Figuren die Augen eingesetzt, so werden sie gerüttelt und angeredet in der Meinung, dass damit die Seele des Verstorbenen, den die Figur vorstellen soll, ihren Wohnsitz darin nimmt" 9. Dr. Meyer wijst er nog op, dat men dikwijls korwar's maakt en ten verkoop aan vreemdelingen aanbiedt. Een dergelijke korwar is echter, zooals de Papoewa het zelf uitdrukt, geen korwar kaku, geen echte korwar, want er is geen rur, geen geest, in 10. Het is dus blijkbaar de voorstelling dat de ziel, die vereerd wordt, steeds op aarde in het beeld blijft. Aan den anderen kant heeft men echter het duidelijk uitgesproken geloof in het bestaan van een zielenland, dat onder anderen volgens de Noeforeezen gelegen is in de onderwereld of op den bodem der zee, waar het aardsche bestaan voortgezet wordt 11. Ten einde nu die twee begrippen met elkander in overeenstemming te brengen, zou men, gelijk wij reeds elders

8 Meyer, Notizen über Glauben und Sitten der Papuas, Jahresbericht des Vereins für Erdkunde zu Dresden, dl. XII (1875), blz. 26.

9 Von Rosenberg, Der Malayische Archipel, blz. 461.

10 Meyer, 0. c., blz. 29. - Eenigszins in strijd met deze duidelijke mededeeling zegt Dr. Meyer echter op eene andere plaats (O. c., blz. 27): "Ich glaube nicht, dass die Papuas sich eine klare Vorstellung darüber machen, ob der Geist wirklich in das Holzbild fährt, oder ob dieses nur eine Art Vermittler ist, um mit dem irgendwo weilenden Geiste in Verkehr zu treten, so wenig sich manch' Einer unter uns in analogen Verhältnissen klar wird über die Natur des Vermittlers, durch den er sein Gebet an die richtige Adresse sendet".

11 Zie: Animisme, blz. 43, en de daar aangehaalde bronnen. 
opmerkten 12, moeten aannemen, dat ook de Papoewas aan den mensch meerdere zielen toekenden. Tot voor korten tijd geleden, vonden wij dit echter nergens uitdrukkelijk vermeld, doch bij de verschillende schrijvers alleen gesproken van ééne ziel, die in het bloed gezeteld is $\mathbf{1 3}$. Eerst uit eene kortelings verschenen verhandeling van den Zendeling Van Balen vernemen wij, dat men, althans op het eiland Roon in de Geelvinksbaai, aan het bestaan van eene tweede ziel gelooft, die met de niën of schaduw vereenzelvigd wordt. Deze ziel nu is het, welke in den korwar wordt gebracht, terwijl de andere naar het zielenland gaat ${ }^{14}$.

Bij de vereering van de afgestorvenen spelen de korwar's eene belangrijke rol. Door middel van den korwar "wird mit dem Geiste der Verstorbenen gesprochen, wenn man seines Rathes und seiner Hülfe bei Krankheiten oder in anderen Gefahren bedarf, sowohl für den glücklichen Erfolg der Tripangfischerei, wie bei einer in Aussicht stehenden Reise. Aus diesem Grunde wird der Korwar in hohen Ehren gehalten, weshalb man ihn auch mit Läppchen ausputzt und ihm Tabak vorlegt, um ihn günstig zu stimmen. Bei solcher Conferenz mit dem Korwar verneigt sich der Sprecher tief vor dem Bilde, in derselben Weise, wie der Papua gewöhnt ist, sich vor einem Höherstehenden zu verbeugen. Geschieht bei solcher Besprechung nichts Besonderes, so ist dies ein Zeichen der Billigung des Korwars; befällt aber dem Rathfragenden ein Zittern, so ist dieses ein Beweis vom Gegentheil, und geht er unbefriedigt fort" 15. Bij de bewoners van het eiland Roon, bedient men zich bij de raadpleging der korwar's van bijzondere personen, mannen zoowel als vrouwen, "die als mediums bekend staan". Zulk een persoon plaatst zich voor het beeld, met eene opgevouwen mat voor zich, en steekt eene cigarette aan. $\mathrm{Na}$ een goeden trek gedaan, den rook ingeslikt en door den neus uitgeblazen te hebben, roept hij den doode bij den naam, en herhaalt dit alles zoo dikwerf tot hij begint te beven. Met de handen in elkander klopt hij nu al harder en harder op de mat, terwijl hij daarbij voor den oningewijde onverstaanbare woorden prevelt, die het advies van den afgestorvene

12 Animisme, blz. 166 , noot.

1s Zie: Animisme, blz. 8, in de daar geciteerde bronnen.

14 Van Balen, Iets over het doodenfeest bij de Papoea's van de Geelvinksbaai, Tijdschr. v. Ind. T. L. en Vk., dl. XXXI, blz. 558 en 562.

15 Van Hasselt, Die Noeforezen, Zeitschrift für Ethnologie, jaarg. VIII (1876), blz. $195-196$.

5e Volgr. II. 
bevatten 16. Het schijnt dat wij hier met eene soort van shamanisme te doen hebben, dat het de voorstelling is dat de ziel uit het beeld komt, in den persoon, het medium, overgaat en door diens mond spreekt. Te eerder zijn wij geneigd dit aan te nemen, daar shamanen-bezweringen bij de Papoewas van het eiland Roon niet onbekend zijn 17.

Is het gebruik van beelden bij de Papoewas van de Geelvinksbaai oorspronkelijk? Onzes inziens is er geen reden, om deze vraag ontkennend te beantwoorden, om te onderstellen dat iets, wat overal elders spontaan voortgekomen is, juist hier aan vreemden zou zijn ontleend. En hiervoor bestaat te minder grond, daar wij nog duidelijk de wijze na kunnen gaan, waarop de Papoewa, zeker geheel zelfstandig, tot dat gebruik van beelden moet zijn gekomen. Men kent de theorie van Spencer, volgens welke de beeldendienst, om dit woord kortheidshalve te bezigen, uit de reliekenvereering voortgekomen is. Deze laatste moet ontegenzeggelijk oorspronkelijker zijn, en is als een uitvloeisel te beschouwen van de bij natuurvolken algemeen bestaande voorstelling, dat de ziel ook na den dood eene zekere betrekking blijft onderhouden met, en dus gaarne

16 Van Balen, Iets over het doodenfeest bij de Papoea's van de Geelvinksbaai, Tijdschr. v. Ind. T. L. en Vk., dl. XXXI, blz. 564.

${ }_{17}$ In zijne in de voorgaande noot geciteerde verhandeling, geeft de Heer Van Balen onder anderen eene beschrijving van zulk eene shamanen-bezwering. Er was, zoo verhaalt hij, op een feest een man vermoord, en daar de geest, die door een gewelddadigen dood het lichaam verlaat, niet vanzelf naar het zielenland gaat, maar in de lucht blijft zweven, moet men hem op weg daarheen helpen. Een lange bamboestaak, met bladeren en wilde vruchten versierd, werd daartoe op het droogloopende strand geplant. 's Middags, toen het strand droog was, verzamelde zich eene menigte volks rondom dien staak, waarbij een groot vuur werd aangelegd van nat hout, zoodat eene dikke rookwolk opsteeg. Een bejaarde man, die hier als medium optrad, vatte den - stak met beide handen vast en begon dien eerst langzaam, vervolgens steeds sneller te schudden, totdat eindelijk alle versierselen er afvlogen. Onder een vervaarlijk geschreeuw der omstanders, liet de man zich achteruit in zittende houding nedervallen, en begon, terwijl hij met de saamgevouwen handen op den grond klopte en zijn geheele gelaat zenuwachtig trilde, te praten, doch zóó, dat ik er geen woord van begreep. De omstanders schenen het echter wel te verstaan, althans naar de veelbeteekenende blikken te oordeelen, die zij elkander toewierpen. Findelijk kwam er een einde aan 's mans extase en ging hij zeer kalm aan den maaltijd, door de betrekkingen des verslagenen angericht. De ziel was nu op weg naar het zielenland, na door den bamboestaak heen in het medium te zijn gevaren en door diens mond te hebben gesproken (Van Balen, O. c., blz. 564-565. Zie ook: Berichten van de Utrechtsche Zendingsvereeniging, dl. XXVII, blz. 134-135, waaraan wij in het voorgaande ook het een en ander hebben ontleend). 
vertoeft in de nabijheid van het lichaam, dat haar voorheen tot verblijfplaats heeft verstrekt. Geen wonder dus dat men bij enkele volken er toe gekomen is, om te trachten, door inbalseming of op andere wijzen, de lijken zoo lang mogelijk in ongeschonden staat te behouden, ten einde een voorwerp te hebben, waardoor men zich voortdurend met de zielen der afgestorvenen in betrekking kon stellen. De moeielijkheid aan het conserveeren van het geheele lijk verbonden, zal echter den wilde in de meeste gevallen er toe gebracht hebben, om alleen enkele relieken te bewaren en die bij de vereering te bezigen. "The soul", dit is toch, volgens de opmerking van Spencer, het geloof bij de natuurvolken, "present in the body of the dead man preserved entire, is also present in preserved parts of his body" 18. Vooral moet dit geloof bestaan ten aanzien van het lichaamsdeel, dat als de hoofdzetel der ziel beschouwd wordt, den schedel. Deze is het dan ook die in de eerste plaats bij den voorouderendienst als medium gebezigd wordt. Hoe is men nu van dit gebruik van relieken tot dat van beelden gekomen? "Any one", aldus Spencer, "asked to imagine a transition from worship of the preserved body, or a preserved part of it, to idol-worship, would probably fail; but transitions such as imagination does not suggest, actually occur. The object worshipped is sometimes a figure of the deceased, made partly of his remains and partly of other substances. Landa says the Yucatanese cut off the heads of the ancient lords of Cocom, when they died, and, as if to cook them, cleared them from flesh; they then sawed off half off the top of the head, leaving the anterior part with the jaw-bones and teeth, and to these halfskulls they joined what they wanted in flesh with a certain cement, and made them as like as possible to those to whom they belonged... In other cases they made for their fathers wooden statues, left the occiput hollow, put in ashes of the burnt body, and attached the skin of the occiput taken off the corpse" 19. Achțereenvolgens heeft men dus, bij de vereering van de afgestorvenen, het gebruik gehad van het geheele gemummificeerde lijk, dan van de eene of andere reliek, in het bijzonder van den schedel, daarop van een beeld, samengesteld uit eene reliek en hout of eenig ander materiaal. Van zulk een beeld tot een, enkel van hout gemaakt, is zeker de overgang niet groot. - Bij de Papoewas van de kusten der Geelvinksbaai nu treft men deze ontwikkelingsvormen naast elkander

\footnotetext{
18 Spencer, Principles of sociology, dl. I, blz. 326.

10 Spencer, O. e., dl. I, blz. 327.
} 
aan, hetgeen zeker in geen geringe mate pleit voor de oorspronkelijkheid van den beeldendienst bij hen. De gewoonte om de lijken op kunstmatige wijze voor ontbinding te bewaren, doo: ze boven een vuur uit te drogen, komt op het eiland Jobi of Jappen voor 20. De dus tot mummies vervormde lijken worden in huis gebracht en tegen den muur gezet of aan den zolder opgehangen. Hoewel dit nu niet uitdrukkelijk vermeld wordt, is het toch zeer waarschijnlijk, dat zij, zoo thans niet meer, dan toch oorspronkelijk bij de vereering dienst hebben gedaan. Daarnaast bestaat het gebruik van enkele relieken bij den voorouderendienst, bepaaldelijk van den schedel, onder anderen bij de Papoewas van Dorei. Is iemand overleden, dan wordt namelijk alleen de romp begraven, doch de schedel bewaard, nadat die op eene bijzondere wijze geprepareerd is, om als medium te worden aangewend, wanneer men zich met de afgestorvenen in betrekking wil stellen 21. In de derde plaats vindt men bij de Papoewas van de Geelvinksbaai, meer bepaaldelijk bij die van de eilanden Roon en Beak of Biak, het gebruik van schedels op beelden bevestigd. Deze beelden zijn als de gewone korwar's; het hoofd is echter van boven open en hol uitgesneden zóó, dat de geheele schedel er in kan staan 22. Ongetwijfeld nu is de gewone korwar uit dezen schedel-korwar voortgekomen.

Naar onze voorstelling is dus de beeldendienst bij de Papoewas van de Geelvinksbaai oorsponkelijk. Dr. Uhle is echter van eene andere meening, beweert dat de beelden in allen gevalle "ihren Typus von Westen aus dem Ostindischen Archipel empfangen haben ", zoodat hij zelfs de vraag meent te mogen opwerpen, "ob es nicht

20 Zie onze verhandeling: Het animisme bij de volken van den Indischen Archipel, blz. 176, en de daar aangehaalde werken van Goudswaard, De Papoewa's van de Geelvinksbaai, blz. 73, en Von Rosenberg, Reistochten naar de Geelvinksbaai, blz. 53. - Behalve aan de kusten van de Geelvinksbaai vindt men het gebruik om de lijken te mummificeeren nog in andere gedeelten van Nieuw-Guinea, in de binnenlanden van de Dorei-baai en te Mairasi op de Zuidwestkust (Animisme, blz. 17, en de daar geciteerde bronnen), verder op de Zuidoostkust (Chalmer und Gill, Neu-Guinea, blz. 268-269).

21 Zie: Animisme, blz. 178, en het daar aangehaalde werk van Goudswaard, De Papoewa's van de Geelvinksbaai, blz. $71-73$ en $77-79$.

32 Van Balen, Iets over het doodenfeest bij de Papoes's van de Geelvinksbaai, Tijdsohr. v. Ind. T. L. en Vk., dl. XXXI, blz. 562 vlg.; Berichten van de Utrechtsche Zendingsvereeniging, dl. XXVII, blz. 78 ; Notulen van de algemeene en bestuursvergaderingen van het Bataviaasch Genootschap van Kunsten en Wetenschappen, dl. XXIII, blz. 150-151. - Eene interessante afbeelding van zulk een schedelkorwar vindt men in het werk van Duperrey, Voyage autour du monde sur la Coquille, Atlas, Plaat XXIX, fig. 1-3. 
möglich, dass die ganze bildliche Verehrung von Ahnen in Neu Guinea aus dem Westen importirt ist", eene vraag, laat hij er echter voorzichtig op volgen, "welche sich noch nicht weiter discutiren lässt" (blz. 4) 23. De streek van den Indischen Archipel "aus welcher die Ahnenbilder der Geelvinkbai ihr Gepräge empfingen, ist noch nicht nachweisbar" (t.a.p.). Er doet zich toch dadelijk eene groote moeielijkheid voor. De korwar's zijn namelijk meestal voorgesteld met een dier in de hand of met een opengewerkt voorwerp bij wijze van balustrade voor zich, waarin men duidelijk dierenfiguren onderscheiden kan. Bij de beelden, die op de eilanden ten Westen van Nieuw-Guinea, met name in de Molukken, gevonden worden, ontbreekt deze eigenaardigheid. Dr. Uhle tracht echter dit bezwaar weg te nemen, door er op te wijzen, dat ons van enkele streken, bepaaldelijk van Halmahera, nog geene beelden bekend zijn. "Hier können sie mit oder ohne Balustraden und mit oder ohne Thiere sein" (t. a. p.). Al dadelijk wenschen wij hiertegen op te merken, dat op Halmahera bij de vereering van de afgestorvenen zoo goed als niet van beelden gebruik gemaakt wordt. Men bedient zich daartoe hier in de eerste plaats van kleine huisjes, de zoogenaamde wongi-ma-falla's. Alleen de ditikki's, de zielen van hen die een gewelddadigen dood gestorven, gesneuveld of vermoord zijn, worden soms door poppen

28 Ook in de benaming korwar schijnt Dr. Uhle een bewijs te willen zoeken voor de juistheid zijner meening, dat de beeldendienst bij de Papoewas van de Geelvinksbaai uit het Westen ontleend is. Hij vergelijkt toch het woord met arinoala of arwaliko, zooals op Timorlaoet de beelden heeten van de vielen van de stichters van dorpen, die als beschermgeesten der plaats vereerd worden. Aangenomen dat deze vergelijking juist is, dan zou de overeenkomst ook hier niet aan ontleening, doch aan stamverwantschap moeten worden toegeschreven. Hetgeen Dr. Uhle echter verder zegt over den oorsprong van het woord aruwala of arwaliko, klinkt zeer onwaarschijnlijk. "Uebrigens", heet het, "geht Timorlaut: arwaliko auf Kawi : arthawalika zurück, - Javan. noch hardhowaliko Name eines Seedrachen, beweist also indirekten hinduischen Einfluss für Timorlaut" (blz. 4). Het Kawi of Oud-Javaansche arddhawalika, ook drawalkka, adrawalika en adrawalika (en niet arthawalika gelijk Uhle schrijft) komt voor in den Bhâratayuddha en den Bhomakâwya als benaming van een mythisch wezen. In den Bhâratayuddha vervult dit wezen dezelfde rol als açasena in het Indisch origineel van het gedicht, en is dus een nâga. De afleiding van arddhawalika is onzeker. Prof. Kern vermoedt dat walika beantwoordt aan het Sanskritsche vyalika = valsch, ;oodat arddhawalika "de zeer valsche" beteekent, zeker geene ongepaste benaming voor een nâga. In het tegenwoordige Javaansch komt het woord voor, in den vorm ánavarnian ardôwalik6 of ánårniam ardôwalikô, als benaming van een der rijkssieraden van Soerakarta, zijnde een gouden voorwerp, dat de gedaante heeft van een vogel met een kop, die zoowat het midden houdt tusschen een menschenhoofd en een slangenkop (Zie 
voorgesteld 24 Van die poppen weten wij wel niets, doch zijn zij misschien van dezelfde gedaante als de beelden, welke voor andere plaatselijke geesten opgericht worden. Deze beelden nu worden gezegd van halve manshoogte te zijn, en zijn bekleed met eenen tjidako of schaamgordel, terwijl zij een lans, schild en zwaard in de handen houden 25. Er is dus volstrekt geen sprake van een voorwerp, dat zij bij wijze van balustrade voor zich hebben. - "Jedenfalls", laat Dr. Uhle op zijne zooeven aangehaalde woorden volgen, "jedenfalls kommen den Balustraden ähnliche durchbrochene Schnitzereien an anderen Gegenständen auf Halmahera vor 26. Durchbrochene Schnitzereien an der Geelvinkbai können von Halmahera stammen, und dort mit der Form des Ahnenbildes, die aus einer anderen Gegend des Archipels gekommen wäre, verbunden worden sein. Doch enthält die Schnitzerei immerhin einen Hinweis auf Halmahera" (t. a. p.). Ons komt deze redeneering uiterst gezocht en zwak voor. Inderdaad heeft Dr. Uhle - hij houde ons de opmerking ten goede - zich hier een weinig te gemakkelijk van eene groote zwarigheid afgemaakt. Het gaat zeker niet aan, waar men, gelijk hịj doet, op allerlei kleinigheden let bij het zoeken naar punten van overeenkomst, belangrijke verschillen op die wijze ter zijde te stellen.

De vraag is nu: bestaat er, afgescheiden van het hier aangeduide verschil, werkelijk zulk eene groote overeenkomst tusschen de beelden van de Geelvinksbaai en die van het Oosten van den Archipel als Dr. Uhle het wil doen voorkomen? Wij meenen deze vraag ontkennend te moeten beantwoorden. Het duidelijkste, zegt Uhle, openbaart zich die overeenkomst "bei den sitzenden Figuren, wo Gesichts-

de af beelding in de Bijdragen tot de T. L. en Vk. v. Nederl. Indië, nieuwe volgreeks, dl. II, blz. 358). Missohien hebben de latere Javanen bij het woord arddhawalkka aan het Sanskritsche mallika, de benaming van eene soort van gans met zwarte pooten en een donkergekleurden snavel, gedacht, en zijn zij op die wijze er toe gekomen, het wezen, dat eigenlijk een nâga is, als een vogel af te beelden. Hoe het zij, het is duidelijk dat zoowel in het Oud- als in het Nieuw-Javaansch arddhawalika of ardowalikb de naam is van een mythisch wezen, dat ò een slang of een vogel is, zoodat het zeer onwaarschijnlijk mag heeten, dat het woord, naar Timorlaoet overgebracht, daar op de beelden van de voorouders zou zijn toegepast, die toch eene mensohelijke gedaante hebben.

24 Campen, De godsdienstbegrippen der Halmaherasche Alfoeren, Tijdschr. v. Ind. T. L. en Vk., dl. XXVII, blz. 442.

25 Campen, O. c., blz. 447.

${ }^{30} \mathrm{Dr}$. Uhle verwijst hier naar de verhandeling van den heer Campen, Eenige mededeelingen over de Alfoeren van Halmahera, opgenomen in de Bijdragen tot de T. L. en Vk. van Nederl. Indië, 4e volgreeks, dl. VIII, waar, op Plaat II fig. 29, afgebeeld is een standaard voor harsfakkels met een opengewerkt voetstuk. 
bildung, Körperhaltung, mangelnde Bekleidung, stilistische Auffassung gleich sehr an Figuren des Ostindischen Archipels erinnern" (blz. 3). Ter vergelijking bedient hij zich ook van de door Dr. Riedel in diens werk "De sluik- en kroesharige rassen tusschen Selebes en Papua" gegeven teekeningen van de beelden der afgestorvenen op Leti en Babar 27. Wij gelooven dat iedereen ons zal toegeven, dat deze beelden in karakter geheel verschillen van de korwar's. Dr. Uhle wijst onder meer op de gelaatstrekken. Doch kan men, om slechts dit eene te noemen, iets karakteristiekers bedenken dan den neus bij de korwar's, met de zoo uiterst wijde neusvleugels en de meestal naar beneden gebogen spits, terwijl bij de beelden van Babar en Leti dit lichaamsdeel die kenteekenen mist, wel breed is, doch gelijkmatig afloopt zonder die plotselinge uitzetting der vleugels, en de punt bij de meesten recht, bij enkelen zelfs een weinig opgewipt is.

In een, ongetwijfeld voornaam, opzicht komen echter, gelijk Uhle te recht opmerkt, de beelden van Leti en Babar in de Molukken met de korwar's overeen, namelijk in de houding. Deze is eene zittende 28: de beenen zijn daarbij echter niet naar voren uitgestrekt of onder het lichaam gevouwen, doch meer of minder hoog voor de borst opgetrokken 29. De beelden van Leti en Babar hebben daarbij meestal de armen gekruist, rustende op de opgetrokken knieën. Hoewel dit bij de korwar's niet het geval is, daar zij meestal, gelijk hierboven gebleken is, een dier in de hand hebben of het voorwerp, dat bij wijze van balustrade voor hen geplaatst is, vasthouden, worden er toch andere beelden aan de Geelvinksbaai gevonden, waarbij op dezelfde wijze de armen gekruist of althans over elkander geslagen zijn. Zoo zien wij onder anderen, op Plaat VII fig. 6 van het werk van Dr. Uhle, een hoofdsteunsel waarvan het voetstuk door een dergelijk beeld gevormd wordt. Een ander voorwerp (Plaat IV fig. 15) is voorzien van een menschenfiguur, eveneens hurkend, met de ellebogen op de opgetrokken knieën gesteund en de kin rustende op de opgeheven handen. - Deze karakteristieke zittende houding is buiten Nieuw-Guinea algemeen verspreid, vooral in het Oosten van den Archipel. Men vindt die, behalve op de

${ }^{27}$ Riedel, O. c., Plaat XXXIV en XXXVII.

28 Gelijk bekend is, heeft men echter ook staande korwar's.

${ }^{29}$ Kortheidshalve zullen wij die houding nu en dan eene "hurkende" noemen, hoewel deze benaming eigenlijk onjuist is. Bij de hurkende positie toch rust het achterste niet op den grond of op het voorwerp waarop men zit, gelijk dit bij de korwar's en andere beelden het geval is, doch op de hielen. 
zooeven genoemde groep van Leti en Babar, nog op verschillende andere eilanden van de Molukken, op Kei, Timorlaoet, LoewangSermata en Kisar, zoowel bij de beelden van de geesteu van pas overleden bloedverwanten, welke lares privati, als bij die van de zielen der stichters van dorpen, welke lares publici zijn, gelijk uit de mededeelingen van Dr. Riedel, in zijn hierboven aangehaald werk, vooral uit de daaraan toegevoegde platen, blijken kan ${ }^{30}$. Ook andere beelden dan die van de afgestorvenen en de voorvaderen, bij voorbeeld van Uplero of den Zonnegod, worden dikwijls op dezelfde wijze, zittend met opgetrokken knieën en over de borst gekruiste armen, voorgesteld. Zoo is dit het geval op Babar, Kisar en Leti $\mathbf{3 1}$. Buiten de Molukken vindt men de hurkende houding onder anderen bij de beelden, welke de Igorroten op Luzon van hunne anito's of afgestorvenen maken. "Diese Anito-Idole sind roh aus Holz geschnitzt und stellen einen Menschen.... dar, sitzend die Arme auf die Knie gestützt und den Kopf zwischen beiden Händen ruhend " 32. - Nu moet er zeker eene natuurlijke reden bestaan hebben, die zoovele verspreid wonende volken er toe gebracht heeft, hunne beelden op dezelfde, voor ons karakteristieke, wijze voor te stellen. Eerder dan, gelijk Dr. Uhle wil, ook in dit opzicht, wat de Papoewas van de Geelvinksbaai betreft, aan overname te denken, ligt het voor de hand om aan te nemen, dat die reden bij hen eveneens aanwezig moet zijn geweest, zoodat zij spontaan er toe gekomen zijn, hunne korwar's dien vorm te geven. Welke nu is die reden? Gaan wij dit kortelijk na.

Hetgeen voor de beantwoording der hier gestelde vraag niet zonder belang is en daarom allereerst moet worden nagegaan, is het feit dat men bij vele volken bij het begraven aan de lijken dezelfde

so Riedel, 0. o., blz. 315, en verder: Plaat XXII flg. 1; XXVII fig. 7 en 8; XXXVIII fig. 8. Zie ook, voor de Zuidwester-eilanden, eene mededeeling van Heymering in het Tijdschr. v. Nederl. Indië, jaarg. 1844, dl. I, blz. 367, en voor Timorlaoet, Forbes, A naturalist's wanderings in the Eastern Archipelago, blz. 327, waar de teekening voorkomt van een beeld in eene zittende houding met opgetrokken knieën, zeker de voorstelling van een afgestorvene (Vergelijk noot 78 beneden). Ook de beelden der voorouders van het eiland Moa, aanwezig in het Ethnographisch Museum te Rotterdam, hebben eene hurkende houding met over de borst gekruiste armen.

${ }^{31}$ Riedel, O. c., Plaat XXXIII fig. 12 ; XXXV fig. 10 en 11 ; XXXVIII fig. 2.

32 Blumentritt, Der Ahnencultus und die religiösen Anschauungen der Malaien des Philippinen-Archipels, blz. 14. Zie ook van denzelfden schrijver: Versuch einer Ethnographie der Philippinen, blz. 29. Bij Ratzel, Völkerkunde, dl. II, blz. 396, vindt men eene teekening van zulk een beeld. 
zittende houding geeft, die wij bij de beelden hebben aangetroffen. Zoo bij de Papoewas van Westelijk Nieuw-Guinea. Van de Arfakkers lezen wij, dat de overledene naar het graf, dat den vorm eener halvemaan heeft, gebracht en daarin geplaatst wordt "in sitzender Haltung, mit emporgezogenen Knien, die Hände über der Brust gekreuzt, und mit dem Rücken gegen die hohle Seite der Gruft gelehnt " 33. Bij de aan de Arfakkers verwante bewoners van Ajambori geeft men, zoodra iemand gestorven is, aan het lijk eene hurkende houding door het in matten te wikkelen en de dijen tegen den buik te buigen; het nederlaten in den grafkuil geschiedt echter zoodanig, dat het aangezicht naar boven gekeerd is ${ }^{\mathbf{3 4}}$. Ook bij de Noeforeezen en op het eiland Roon worden de dooden met opgetrokken knieën begraven, in de houding, gelijk een der berichtgevers zich uitdrukt, die de vrucht in den moederschoot heeft 35. - Algemeen verspreid komt dit gebruik, om in zittende houding te begraven, voor in de Molukken. "Opgericht ", aldus deelt Dr. Brumund van de Alfoeren van Ceram mede, "de knieën tegen de borst samengevouwen, de armen en handen stijf tegen het lichaam en hoofd gedrukt, wordt de overledene zoolang in die houding vastgehouden, tot het lijk geheel is verstijfd. In eene spits toeloopende mand gepakt en goed gesloten, wordt hetzelve zonder eenige plechtigheid in eene of andere grot weggelegd" 36. Ook Dr. Riedel zegt dat bij de Patasiwa, in het Westen von Ceram, de dooden zittend, met de knieën tegen de borst gebonden, in het graf geplaatst worden. In eenige dorpen in het Noordwesten worden van volwassen mannen de lijken niet begraven, doch naakt in gomutu, de vezelen van den Arenga saccharifera, gewikkeld, op stellages in het bosch nedergelegd. Ook dit geschiedt in eene hurkende positie ${ }^{37}$. Van de Aroe-eilanders heet het, dat de dooden bij hen in eene zittende houding met

s3 Von Rosenberg, Der Malayische Archipel, blz. 534. Zie ook van denzelfden schrijver: Reistochten naar de Geelvinksbaai, blz. 92.

s4 Nieuw-Guinea, ethnographisch en natuurkundig onderzocht en beschreven, blz. 162.

35 Van Hasselt, Eenige aanteekeningen aangaande de bewoners der Noordwestkust van Nieuw-Guinea, meer bepaaldelijk den stam der Noeforeezen, en Van Balen, Iets over het doodenfeest bij de Papoea's van de Geelvinksbaai, Tijdschr. v. Ind. T. L. en Vk., dl. XXXI, blz. 589 en 557.

36 Brumund, Aanteekeningen gehouden op eene reis in het Oostelijk gedeelte van den Indischen Archipel, Tijdschr. v. Nederl. Indië, jaarg. 1845, dl. II, blz. 68.

37 Riedel, De sluik- en kroesharige rassen tusschen Selebes en Papua, blz. 142. Het sohijnt dat het gebruik om zittend te begraven niet op geheel Ceram bestaat. Van de Patalima in het Oosten van het eiland vinden wij, althans bij Dr. Riedel, niets dearomtrent vermeld. 
de kin op de knieën rustende en de handen over de scheenbeenen samengevouwen, in een vierkanten, ongeveer drie voet langen en breeden kuil, begraven worden ${ }^{38}$. Verder ontmoet men het gebruik op de Zuidwester-eilanden. Volgens den Heer Bosscher wordt het in lijnwaad gewikkelde lichaam, in eene hurkende houding samengedrongen, met de handen tegen het gelaat gedrukt, in het graf bijgezet 39. Eenigszins anders luidt, bepaaldelijk wat de groep van Leti-Moa-Lakor en Loewang-Sermata betreft, het bericht van den Heer Riedel. Op deze eilanden krijgen volgens hem de lijken wel eene zittende of hurkende positie, doch worden zij op zijde liggende in het graf nedergelaten ${ }^{40}$. - Naar de Kleine Soendaeilanden overgaande, noemen wij in de eerste plaats de Soembaneezen. Het lichaam wordt, onmiddelijk als iemand den laatsten adem heeft uitgeblazen, in zittende houding gebracht en met lijnwaad omwikkeld; daarbij worden de beenen gebogen, zoodat de voetzolen den grond raken en de knieën tot bij de borst komen, de ellebogen tusschen de knieën en de beide handen aan de wangen gebracht. Het graf bestaat uit een ronden kuil, in den vorm van eenen waterput, niet breeder en ook niet dieper dan om het lijk in die zittende houding te bevatten, en wordt door eenen steen gesloten ${ }^{41}$. Van de Savoeneezen deelt Dr. Riedel mede, dat "the bodies are buried in a sitting position; with the face towards the West" 42. Dit gebruik schijnt echter niet op alle eilanden van de groep voor te komen. De Heer Donselaar althans vermeldt dat de lijken in den regel in eene liggende houding begraven worden en dat alleen de deo-rae, in het Maleisch tuwan-tanah geheeten, de persoon die bij godsdienstige plechtigheden als priester fungeert, daarop eene uit-

38 Bosscher, Aanteekeningen omtrent de Aroe-eilanden, Tijdschr. v, Ind. T. L. en Vk., dl. II, blz. 363. De Heer Riedel zegt (O. c., blz. 267) dat als iemand overleden is, hij in eene zittende houding, tusschen hout geklemd, onder het huis geplaatst wordt. Hoewel de sohrijver het niet uitdrukkelijk vermeldt, is het zeker zijne bedoeling, dat het lijk ouk in die houding in het graf gelaten wordt.

${ }^{39}$ Bosscher, Schets der Zuidwestereilanden, Tijdschr. v. Ind. T. L. en Vk., dl. II, blz. 446. Zie ook de mededeeling van Heymering in het Tijdschr. v. Nederl. Indië, jaarg. 1844 , dl. I, blz. 367 .

40 Riedel, O. c., blz. 328 en 394.

41 Roos, Bijdrage tot de kennis van taal, land en volk van het eiland Soemba, Verhandelingen v. h. Bat. Gen. v. K. en W., dl. XXXVI, blz. 55. Zie ook: Soemba en de Soembaneezen naar de mededeelingen van den Zendeling-leeraar Van Alphen, Tijdschr. v. Nederl. Indië, jaarg. 1884, dl. I, blz. 208.

42 Riedel, The Sawu Group, Revue coloniale internationale, jaarg. 1885, dl. I, blz. 309 . 
zondering makkt deze wordt zittend ter aarde besteld 43. Bij de Mangaraiers van West-Flores en de Dou-Donggo, de heidensche stam die in het gebergte van Oost-Soembawa gevestigd is, worden, evenals bij de Soembaneezen, de dooden in een ronden kuil, die met een platten steen gesloten wordt, bijgezet: de houding waarin dit geschiedt, is ook hier eene hurkende of zittende ${ }^{44}$. - Bekend is de wijze waarop de Alfoeren der Minahasa hunne dooden behandelen. Dezen worden begraven in vierkante steenen potten van ongeveer een meter lengte en breedte, timbukar of tiwukar geheeten, welke potten gesloten worden door een min of meer dakvormig deksel, zoodat het geheele toestel het aanzien heeft van eene kleine woning. Reeds voor dat iemand gestorven is, gedurende de laatste teekenen van het wegsnellende leven, schikt men hem in eene zittende houding, met de knieën opgetrokken en de armen over de borst gekruist. Met lijnwaad omwonden, wordt hij in die positie in den tiwukar geplaatst 45. Eenigszins analoog handelen de Alfoeren van Tomboekoe op Oost-Celebes. In plaats van in een steenen pot, wordt bij hen echter het lijk, na in eene hurkende positie te zijn gebracht, in eene vierkante kist bijgezet 46. - Hetzelfde doen ook de Igorroten van het eiland Luzon. "Der Leichnam", aldus lezen wij, "wird sitzend in einen kistenartigen Sarg gesteckt, welcher, wenigstens in Lepanto, aus einem Holze verfertigt wird, das angeblich die Fäulniss verhindert" 47. - Minder verspreid is het gebruik van het zittend begraven in het Westen van den Archipel. In de eerste plaats treft men het bij de Orang-Lom, de heidensche bewoners van de binnenlanden van Bangka, aan ${ }^{48}$. Verder heet het van de Orang-Bĕnoewa van Malaka, dat bij sommige stammen de dooden bijgezet worden "in a sitting posture, in a grave from three to six

43 Donselaar, Aanteekeningen over het eiland Savoe, Mededeel. v. w. h. Nederl. Zend. Gen., dl. XVI, blz. 313.

4 Freyss, Reizen naar Mangarai en Lombok, Tijdschr. v. Ind. T. L. en Vk., dl. IX, blz. 510 ; Zollinger, Verslag van eene reis naar Bima en Soembawa, blz. 129. Zollinger zegt wel niet uitdrukkelijk dat de Dou-Donggo de dooden hurkend begraven, doch blijkt dit voldoende uit de mededeeling van Treyss.

45 Graafland, De Minahasa, dl. I, blz. 329 vlg. Zie over de tiwukar's onder anderen een opstel van den Heer Riedel in het Tijdschr. v. Ind. T. L. en Vk., dl. XIV, blz. 379 vlg.

${ }^{46}$ Bosscher, Schets van de rijken van Tomboekoe en Banggaai, Tijdschr. v. Ind. T. L. en Vk., dl. II, blz. 76.

47 Blumentritt, Versuch einer Ethnographie der Philippinen, blz. 28.

48 De Orang-Lom of Belom op het eiland Bangka, Tijdschr. v. Ind. T. L. en Vk., dl. XI, blz. 392. 
cubits deep" 49, terwijl op Sumatra bij den Batakschen stam der Karo-karo de lijken der guru's of wichelaars op die wijze behandeld worden $\mathbf{5 0}$.

De gewoonte om de lijken bij het begraven eene zittende houding te geven, is niet alleen tot den Indischen Archipel beperkt. Ook in Polynesië komt zij voor, onder anderen op Nieuw-Zeeland, Tahiti en Hawai. "Man begrub die Todten.... in kauernder Stellung, indem man das Haupt auf die Kniee legte" 51. Evenzoo bestond, om van andere volken te zwijgen, het gebruik voorheen in Europa. "There can be no doubt", aldus vat Sir John Lubbock de resultaten van de door verschillende geleerden ingestelde onderzoekingen omtrent de wijze, waarop in de oudste tijden, in ons werelddeel, de dooden behandeld werden, samen, "there can be no doubt that in the Neolithic Stone Age it was usual to bury the corpse in a sitting or contracted posture; and, in short, it appears probable, although far from being satisfactorily established, that in Western Europe this attitude is characteristic of the Stone Age, cremation of that of Bronze; while those cases in which the skeleton was extended may be referred, with little hesitation, to the Age of Iron" 52. Hoe is het gebruik van het begraven in eene zittende houding ontstaan? Men heeft hiervan verschillende verklaringen gegeven. "Wenn ", zegt onder anderen Peschel, "wir nichts Näheres über die Ansichten der geistig so gutbegabten, früher so gröblich unterschätzten Hottentotten wüssten, so würde es schon genügen, dass sie den Verstorbenen vor der Beerdigung dieselbe Stellung geben, die sie einst als Keim im Mutterschoosse eingenommen hatten, denn die Bedeutung dieses sinnigen Brauches ist es, dass die Toten einer neuen Geburt im Dunkel der Erde entgegenreifen sollen" 53. Deze verklaring is zeker zeer vernuftig, doch kan men vragen, hoe wilden, tenzij bij toeval en vanzelf dus alleen bij uitzondering,

49 Newbold, Political and statistical account of the British Settlements in the Straits of Malacca, dl. II, blz. 408. - Zie ook: Borie, Notice sur les Mantras, Tijdschr. v. Ind. T. L. en Vk., dl. X, blz. 429; Journal of the Straits Branch of the Royal Asiatic Socieby, jaarg. 1878, blz. 112.

50 De Haan, Verslag van eene reis in de Bataklanden, Verhandelingen v. h. Bat. Gen. v. K. en W., dl. XXXVIII, blz. 42.

51 Waitz, Anthropologie der Naturvölker, dl. VI, blz. 405, 408 en 411.

52 Lubbock, Pre-historic times, blz. 156-157.

53 Peschel, Völkerkunde, blz. 271. - De Zendeling Van Hasselt zinspeelt blijkbaar op deze verklaring, waar hij, gelijk wij boven gezien hebben, van de Noeforeezen zegt, dat zij de dooden begraven in de houding, die de vrucht in den moederschoot heeft. 
dan wel tot de wetenschap van de houding, die het ongeboren kind in den moederschoot heeft, gekomen zijn? - Gerland wil de zaak op eene andere wijze vitleggen. Op Tahiti, en zoo ook op Hawai, worden alleen lieden uit het volk zittend begraven. "Soll ", vraagt hij nu , "die sitzende Stellung vielleicht damit im Zusammenhang stehen, dass die Geringeren vor den Vornehmeren immer sitzen mussten? Dass es also eine Art von Gottesverehrung wäre?" $\mathbf{5 4}$ - Onzes inziens is de verklaring van het gebruik eene andere. Men geeft aan het lijk de houding, die de afgestorvene bij zijn leven placht aan te nemen. Interessant in dit opzicht is hetgeen ons onder anderen van de bewoners van Warekauri verhaald wordt. Bij hen "wurde jeder nach seinem Beruf begraben, ein Fischer also ẉard ins Meer gestossen, ein Vogelfänger in kauernder Stellung zwischen zwei Bäumen begraben, das Gesicht nach der Stelle gerichtet, die er am meisten besucht hatte " 55. Zoo is het ook met het begraven in eene zittende houding. "Pour l'imagination de la plupart des hommes primitifs ", aldus zeer juist Letourneau, "la mort est un long sommeil. Dans cette supposition, rien de plus naturel que de donner au cadavre l'attitude du repos que l'on a l'habitude de prendre au coin du feu, le soir, après une journée de chasse ou de guerre " 56. En deze houding welke men, uitrustende in het hoekje van den haard, zoo gaarne pleegt aan te nemen, is de zittende met opgetrokken knieën. Dit is ook bij de volken van den Indischen Archipel het geval. Wel is heden ten dage bij de eenigszins beschaafde stammen, de meest ordentlijke, welgemanierde wijze van zitten die met gekruiste beenen, duduk bersila gelijk dit in het Maleisch heet, doch deze is waarschijnlijk overgenomen van de Hindû's, bepaaldelijk misschien afgezien van de Hindûsche steenen beelden, in de eerste plaats van de Buddha-beelden. Dit schijnt de benaming bèrsila aan te duiden, want het grondwoord hiervan sila, dat ook in het Javaansch en Soendaneesch, ja zelfs in het Tagalsch in denzelfden zin voorkomt, is niets anders dan het Sanskritsche

54 Waitz, Anthropologie der Naturvölker, dl. VI, blz. 408.

55 Waitz, O. e., dl. VI, blz. 413-414.

${ }^{56}$ Letourneau, La sociologie d'après l'ethnographie, blz. 207-208. — Eene dergelijke verklaring geeft ook Von Hellwald van het gebruik. Volgens hem is "die symbolische Auslegung die annehmbarste, wonach der Todte blos auf kurze Dauer und gewissermassen in der Gestalt in seiner einsamen Behausung Platz nimmt, dass er, nach kurzer Rast, wieder aufspringen, die Waffen und sonstigen Geräthschaften, die ihm zur Seite liegen, ergreifen, mit der vorhandenen Nahrung sich stärken und so in der Hauptsache ein seinem früheren, ähnliches Leben fortsetzen könne" (Von Hellwald, Culturgeschichte in ihrer natürlichen Entwicklung, dl. I, blz. 85-86). 
çila $=$ steen, zoodat duduk bërsila oorspronkelijk letterlijk : zitten als een steen, scil. een steenen beeld, moet hebben beteekend. Is deze ondersteling juist, dan zou dus deze wijze van zitten niet oorspronkelijk zijn 56a. Zeker is het, dat nu nog bij enkele stammen het bĕrsila niet bekend is. Zoo zegt Von Rosenberg van de Niasers, dat zij bij het zitten de beenen niet onder het lijf geslagen, doch voor het lijf opgetrokken hebben ${ }^{57}$. Dit is ook de wijze van zitten, zooals Dr. Riedel ons mededeelt, bij de stammen van CentraalCelebes, de Alfoeren van de Minahasa, althans voorheen, bij de bewoners van Ceram, Aroe, Kei, de Zuidwester-eilanden, Timor, Alor, enz. Ook bij de Igorroten zit men met opgetrokken beenen, "die Arme auf die Knie gestützt und den Kopf zwischen beiden Händen ruhend " 58. Zelfs bij de volken, die het bĕrsila hebben, doet men dit veelal alleen in deftig gezelschap, doch pleegt men, als men het zich gemakkelijk maken wil, gaarne de beenen op te trekken, daarbij de armen over de borst te kruisen of met de handen de knieën te omvatten, bertjangkung berrpěluq lutut, zooals de Maleier dit noemt, dan wel de ellebogen op de knieën te plaatsen en met de opgeheven handen kin en wangen te steunen 58a.

$\mathrm{Na}$ het voorgaunde kan het ons duidelijk zijn, hoe men bij zoovele volken er toe gekomen is, de beelden van de afgestorvenen zittend met opgetrokken knieën voor te stellen. Niets natuurlijker toch dan dat men den doode afbeeldt, gelijk men hem tijdens zijn leven het meest, en immers nog het laatst vóór zijne begrafenis, gezien heeft. Zulk een zittend beeld doet zeker, meer dan een staand, aan een levend mensch denken 58b. Doch er is meer. Waar

56a Intusschen moet hier opgemerkt worken, dat bij de verwante bewoners van Polynesië, die toch nooit met de Hinda's in aanraking zijn geweest, het zitten met gekruiste beenen regel is (Ellis, Polynesian researches, dl. I, blz. 189).

57 Von Rosenberg, Verslag omtrent het eiland Nias, Verhnndelingen v. h. Bat. Gen. v. K. en W., dl. XXX, blz. 27. Zie ook van dezelfden schrijver: Der Malayische Archipel, blz. 168.

58 Blumentritt, Der Ahnencultus und die religiösen Anschauungen der Malaien des Philipinen-Archipels, blz. 14, waar de zittende anito-beelden (zie boven blz. 618) gezegd worden "einen Menschen in der Ruhelage eines Igorroten" voor te stellen.

58 Niet alleen in het hoekje van den haard, doch zelfs in staatsie zittende, wordt de hurkende houding wel eens aangenomen. Zoo op Ceramlaoet. "Op fijne matten gehurkt zittende, krijgen de radja's en orangkaja's achter zich drie, de overige hoofden zoomede de imam, het hoofd der geestelijken, twee kussens" (Riedel, De sluik- en kroesharige rassen tussehen Selebes en Papua, blz. 155).

58b Vrouwen plegen, volgens mededeeling van den Heer Riedel, minder dan de mannen met opgetrokken knieën te zitten, doch zijn meer gewoon de beenen onder het lichaam te vouwen of naar achteren om te slaan. In overeenstemming daarmede 
het mummificeeren bestaat, geschiedt dit vaak, gelijk het begraven, in eene zittende houding. Zoo op Oostelijk Jappen. Daar brengt men den afgestorvene in eene hurkende positie op een rooster, waaronder gedurende een paar dagen sterk gestookt wordt. Acht men het lijk genoegzaam droog, dan zet men het in die positie in den eenen of anderen hoek van het huis neer 59. Erkent men nu de juistheid van de theorie van Spencer, dat de beeldendienst uit de reliekenvereering voortgekomen is, dan is het zeer natuurlijk, dat toen men begon, beelden van de afgestorvenen te maken, men dezen ook zal hebben gevormd naar het model van de gemummificeerde lijken, in de plaats waarvan zij gebruikt moesten worden. Het blijkt dus dat er voldoende reden bestaat, om aan te nemen, dat de Papoewas geheel zelfstandig er toe gekomen zijn, aan de korwar's eene zittende houding met opgetrokken knieën te geven, zoodat het geheel onnoodig is daarin, gelijk Uhle wil, een bewijs van vreemden invloed te zien.

Gelijk wij hierboven reeds terloops opmerkten ${ }^{60}$, worden bij de Papoewas, behalve korwar's, nog andere beelden gevouden. Zoo wordt door Dr. Uhle tal van voorwerpen beschreven, die met menschenfiguren versierd zijn. In de eerste plaats komen deze figuren aan de amuletten (Plaat IV fig. 1-6) voor, die aan een koordje om den hals gedragen worden. Deze amuletten bestaan namelijk in den regel uit kleine stukjes hout of liever staafjes, waaraan de vorm van een menschelijk aangezicht of een menschelijk lichaam gesneden is $60^{2}$. Dat die figuren de afgestorvenen voorstellen, is onzes inziens niet zijn de vrouwelijke beelden soms in die houding voorgesteld. Zoo op Loewang-Sermata en Leti (Riedel, De sluik-en kroesharige rassen tusschen Selebes en Papua, blz. 315, en Plaat XXXVIl fig. 7 ), en eveneens op Moa, gelijk uit de voorwerpen van dit eiland af komstig, aanwezig in het Ethnographisch Museum te Rotterdam, blijken kan.

59 Von Rosenberg, Reistochten naar de Geelvinksbaai, blz. 53. - Hetzelfde had ook op Tahiti plaats. "Fürsten balsamirte man ein, d. h. man rieb den Körper mit Oel, nachdem man die Fingeweide entfernt hatte und trocknete ihn in der Sonne; dann ward er bekleidet, in sitzende Stellung gebracht und vor ihn ein Altar, auf welchem man täglich opferte, gesetzt" (Waitz, Anthropologie der Naturvölker, dl. VI, blz. 408). Ook op Hawai werd bij het mummificeeren aan de lijken meestal eene zittende houding gegeven (Waitz, O. e., dl. VI, blz. 407).

${ }^{60}$ Zie boven blz. 617.

60a Dergelijke "Stabamulete" worden ook Westelijk van Nieuw-Guinea in den Indischen Archipel aangetroffen. "Von den Manobos auf Mindanao", zegt Uhle (blz. 4), "besitzt das Dresdner Museum zwei Halsbänder, an denen 4-8.5 $\mathrm{cm}$. lange, sonst ähnlich geformte und mit einem menschlichen Kopf beschnitzte Amulethölzchen aufgereiht sind. Aebnliches scheint auf Borneo vorzukommen (nach Ausland 1882, 
twijfelachtig. Verder vindt men dergelijke menschenfiguren aan tal van voorwerpen voor huishoudelijk gebruik, bij voorbeeld aan de houten stelen van lepels, waarvan op Plaat IV fig. 7-19 verscheidene zijn afgebeeld. Bekend zijn ook de houten hoofd- of liever neksteunsels, voorwerpen in den vorm van een laag en smal bankje, die de Papoewas bij het slapen gebruiken, om er den nek op te leggen. Deze neksteunsels, "Nackenschemel" gelijk Dr. Uhle ze benoemt, zijn in den regel met snijwerk versierd, waarin, meer of minder duidelijk, menschenfiguren te onderscheiden zijn. Zoo spraken wij hierboven reeds van een hoofdsteunsel (Plaat VII fig. 6), waarvan het voetstuk bestaat uit een beeld in zittende houding, met voor de borst opgetrokken knieën, waarop de over elkander geslagen armen rusten. Een ander voorwerp van dien aard (Plaat VII fig. 2) wordt gevormd door "Zwei menschliche Figuren, einleibig, nach entgegengesetzten Seiten gewendet, mit den Händen auf kleine Säulen sich stützend; über ihnen zwei schlangenartige Thiere, welche die obere Platte zu tragen scheinen" (blz. 7). - Omtrent de beteekenis van deze menschenfiguren, hieraan zoowel als aan de andere voorwerpen voor huishoudelijk gebruik, kan geen twijfel bestaan. Zij is eene godsdienstige. "Man darf", zegt Uhle onzes inziens te recht, "den menschlichen Figuren keine besonderen Bedeutungen unterschieben, je nachdem ob sie an Amuleten oder an gewöhnlichen Gegenständen des Gebrauchs vorkommen. Sind die Darstellungen an Amuleten religiöse, so dürften es auch die anderen sein. Jedes so verzierte Geräth dürfte damit zugleich ein religiöses Emblem, eine geisterhafte Belebung erhalten haben. Es wirft dies ein eigenthümliches Licht auf die Gespensterfurcht und den Cultus der Papuas. Was von diesem bekannt ist, lässt jenes nicht unerklärlich erscheinen" (blz. 5).

Behalve menschenfiguren, vindt men aan de door Uhle beschreven voorwerpen dikwijls dierenfiguren. Zoo ziet men op Plaat VII fig. I een hoofdsteunsel afgebeeld, bestaande uit een enkel dier, dat gelijk Dr. Meyer mededeelt, volgens het zeggen van de Papoewas, een hond moet verbeelden. "Ohne diese Mittheilung wäre das Thier als

p. 819)" - Dr. Uhle had hier nog op de Bataks kunnen wijzen. Dezen bezitten eveneens als amuletten kleine, $8-9 \mathrm{~cm}$. lange, staafjes, waaraan de vorm van een menschelijk aangezicht gesneden is. Sommigen hebben aan het boven-, anderen san het benedeneinde eene opening, ter opname van een toovermiddel. Iedereen heeft steeds zulk een voorwerp in zijnen knapzak bij zich. Een tweetal van dergelijke amuletten zijn door Dr. Hagen afgebeeld op Plaat I van zijn "Rapport über eine im December 1883 unternommene wissenschaftliche Reise an den Toba-See", Tijdschr. v. Ind. T. L. en Vk., dl. XXXI, blz. 328 vv. 
Hund kaum zu erkennen", zegt Uhle (blz. 7). De rolstaart, het languitgerekte lichaam en eenigermate de breede kop doen onzes inziens eerder aan een cuscus denken. Zou, zoo het dier werkelijk een cuscus voorstelt, de zegsman van Dr. Meyer dit niet geweten hebben? Misschien wel, doch heeft hị, begrijpende dat hij toch niet verstaan zou worden, zoo hij den inlandschen naam van den cuscus opgaf, eenvoudig een dier genoemd, dat naar zijne voorstelling er eenigszins nabij kwam en den vrager bekend kon zijn. $\mathrm{Nu}$ geven wij toe, dat een cuscus al zeer weinig op een hond gelijkt. Doch dit doet een paradoxurus evenmin, en toch noemen de Alfoeren van de Minahasa, als zij het dier aan de Europeanen willen aanduiden, den longkoi, Paradoxurus Musschenbroekii, andjing-hutan = wilde hond. Een ander hoofdsteunsel (Plaat 'VII fig. 3) verbeeldt een vogel, "der Schnabel dem eines Sumpfvogels ähnlich, die Beine aber davon verschieden" (blz. 7). - Naast deze voorwerpen, die enkel een dier voorstellen, ontmoet men tal van andere, waaraan menschenen dierenfiguren gecombineerd voorkomen. Hierboven hebben wij dit reeds van de korwar's gezien 61. Enkelen toch houden een dier, bepaaldelijk een visch, in de hand; anderen hebben, bij wijze van balustrade, een opengewerkt voorwerp voor zich, waarin, meer of minder duidelijk, dierenfiguren, twee tegenover elkander gekeerde slangen, of, gelijk bij een paar exemplaren van het Ethnographisch Museum alhier, hagedissen of leguanen, te herkennen zijn. Ook bij de amuletten zij̄n de menschenfiguren dikwijls met dierenfiguren gecombineerd, en evenzoo bij de andere voorwerpen voor huishoudelijk gebruik, lepels, hoofdsteunsels, enz. Hier is de combinatie dikwijls zoo ver doorgevoerd, dat de voorstelling half menseh-, half diervormig is. Zoo ziet men dikwijls "eine menschliche Figur in Verbindung mit einem Thierkopf", waarbij "die Figur entweder ganz über dem Thierkopf, oder halb im Rachen desselben sitzt, oder bis an den Kopf in diesem versteckt ist" (blz. 5). Het dier is in dit geval een krokodil. Ook aan andere voorwerpen vinden wij een krokodillenin vereeniging met een menschenfiguur, gelijk aan den steel van eene bijl op Plaat II fig. 7. Kortom, om de woorden van Dr. Uhle te gebruiken, bijna altijd "erscheint ein Thier als ständige Begleitung einer menschlichen Figur, welche religiöse Bedeutung hat. Die Differenz in der Art der Thiere und der Manier ihrer Vereinigung mit den menschlichen Figuren erscheint daneben untergeordnet" (blz. 5).

Welke nu is de beteekenis van deze dierenfiguren, zoowel die

61 Zie boven blz. 615 .

5e Volgr. II. 
welke alleen voorkomen als met een menschenfiguur verbonden zijn? Volgens Dr. Meyer beweren de Papoewas "dass die einzelnen Thiere an den Ahnenbildern Fische als Speise vorstellen" (blz. 4), en dat ook "die Schnitzereien der Amulete meist einen, ein Thier essenden Menschen" verbeelden (blz. 5). Te recht meent echter Dr. Uhle, dat "um als ursprüngliche zu gelten, diese Bedeutung zu trivial scheint" (blz. 4). Hij wijst er op, dat dikwijls "die menschliche Figur sich hinter oder halb oder ganz in dem Thiere verbirgt", zoodat hier "eher das Thier den Menschen, als dieser jenes umgekehrt vergewaltigt" (blz. 5). Daarnaar, gaat hij voort, "hat sich die Deutung zu richten. Vielleicht verkennt ein Theil der heutigen Papuas das ursprüngliche Verhältniss, indem er das Thier als Speise ansieht. Dann aber entsprechen also die Darstellungen im Allgemeiuen nicht einer jetzt bestehenden Auffassung von ihnen, sondern einer früher bestehenden ursprünglicheren, die jetzt zum Theil oder ganz verloren ist, und da die Darstellungen mit letzterer noch übereinkommen, so ist diese die formal wichtigere. Aus den Darstellungen ist also die ursprünglichere, vielleicht immer noch z. Th. in Neu Guinea bekannte, Bedeutung zu erschliessen" (t. a. p.). Deze oorspronkelijke beteekenis zullen wij nu trachten op te sporen.

Het is van genoegzame bekendheid dat in den Indischen Archipel evenals elders de vereering van dieren voorkomt. Als eene der voornaamste uitingen daarvan is het totemisme te beschouwen. Wat totemisme is, kan bekend zijn. Het woord is afkomstig van de NoordAmerikaansche Indianen. Elke stam hier heeft, onder de benaming totem, het een of ander dier, dat als een fetis vereerd wordt, waarnaar de stam heet, en waarvan zijne leden hunne af komst afleiden. De Roodhuid, die den wolf bij voorbeeld als zijn totem erkent, heeft ook den wolf tot beschermgeest, draagt diens naam en beschouwt zich als aan de geheele soort verwant. Het totemisme is dus eigenlijk de vereering van dieren als voorouders. Spencer wil het totemisme verklaren uit de bij onbeschaafde of half beschaafde volken veelvuldig voorkomende gewoonte, personen, naar hunne meest kenmerkende hoedanigheden, bijnamen te geven, aan dierennamen ontleend, als: wolf, tijger, beer, bever, vos, enz. "Given", aldus gaat nu Spencer voort, "a belief in the still-existing other self of the deceased ancestor, who must be propitiated; given the survival of his metaphorical name among his grandchildren, great-grandchildren, etc.; and the further requisite is that the distinction between metaphor and reality shall be forgotten. Let the tradition of the ancestor fail to keep clearly 
in view the fact that he was a man called the Wolf - let him be habitually spoken of as the Wolf, just as when alive; and the natural mistake of taking the name literally will bring with it, firstly, a belief in descent from the actual wolf, and, secondly, a treatment of the wolf in a manner likely to propitiate him - a manner appropriate to one who may be the other self of the dead ancestor, or one of the kindred, and therefore a friend" 62. Volgens Spencer is men dus, door hetgeen hij noemt "a misinterpretation of nicknames", door eene verkeerde, eene letterlijke opvatting van aan dieren ontleende bijnamen, van de vereering der voorouders tot het totemisme gekomen. Tegen deze verklaring bestaat eene gewichtige bedenking. Men stelle zich toch een wilde voor, die zelf geheeten is naar een dier, wiens kinderen eveneens naar dieren genoemd zijn, wiens vader en grootvader, nog in leven, toegesproken worden met namen als Vos en Beer, en vrage zich af, of zoo iemand behoefte zou gevoelen, het feit, dat een zijner voorvaders Wolf heette, te verklaren door de hypothese, dat die grootvader werkelijk een Wolf was? Onzes inziens moet het antwoord ontkennend luiden. Zulk eene "misinterpretation of nicknames" in eene omgeving, waar het geven van "nicknames" als regel bestaat, is niet denkbaar. De verbindende schakel tusschen het totemisme aan den eenen en den dienst der afgestorvenen aan den anderen kant is dan ook, gelijk wij reeds elders hebben trachten aan te toonen ${ }^{63}$, de zielsverhuizing, het geloof dat de ziel na het overlijden in het lichaam van het een of ander dier overgaat. Met het diersoort toch, waarin men de zielen der afgestorvenen bij voorkeur geincarneerd denkt, moet men zich natuurlijk ook verwant gevoelen. En dit is niet overdrachtelijk bedoeld, doch volkomen ernstig gemeend. Wij moeten, ten einde ons daarvan eene verklaring te geven, wel in het oog houden dat voor den wilde, den onbeschaafde, er niet zulk eene scherpe afscheiding bestaat tusschen de menschen- en dierenwereld, als wij ons van der jeugd af, door de absolute tegenstelling van het redeloos dier en den redelijken mensch hebben leeren denken. "Sowohl dem Bewusstseinszustande als auch den Willensbestrebungen nach", aldus Schultze, "unterscheidet sich der Naturmensch fast gar nicht, auf etwas entwickelteren Stufen sehr wenig von den Thieren. Die Welt der Thiere

\footnotetext{
62 Spencer, The origin of animal-worship, Essays: scientific, political, and speculative, dl. III, blz. 108. Zie ook: Principles of sociology, dl. I, blz. 359 vv.

63 Zie onze verhandeling: Het animisme bij de volken van den Indischen Archipel, blz. 67 vv.
} 
ist auch die seinige. Beider Interessen sind dieselben. Es ist also fast noch gar kein Unterschied zwischen dem Naturmenschen und dem höher organisirten Thiere. Wenn aber der Mensch noch nicht von diesen Thieren verschieden ist, so kann er sich auch noch nicht als ein von den Thieren gänzlich Verschiedenes wahrnehmen; sein eigenes Thun und Treiben und das der Thiere stimmen überein; es sind dieselben Bestrebungen, dieselben Motive bei beiden: der Naturmensch findet im Thiere sich selbst wieder; deshalb betrachtet er es nothwendig als Seinesgleichen, als ihm in jeder Hinsicht ebenbürtig" 63a. Dat bij eene dergelijke beschouwing de leer der ziels verhuizing vanzelf tot het begrip van de verwantschap van den mensch met, van zijne afstamming van, bepaalde dieren moet voeren, spreekt vanzelf. De dieren nu, dus tot den rang van voorouders verheven, worden vereerd gelijk men andere voorouders vereert. Ziedaar het totemisme.

Ook in den Indischen Archipel komt het totemisme voor. Tal van dieren zijn er, die op grond van de zielsverhuizing en het daaruit voortvloeiende begrip van verwantschap en afstamming, hier vereerd worden 64. Daartoe behooren in de eerste plaats krokodillen, bij de Maleiers, Bataks, Javanen, Soendaneezen, Makassaren, Boegineezen, Timoreezen, bij de bewoners van de Moluksche eilanden en de Tagala's van de Philippijnen 64a $_{\mathrm{a}}$; verder tijgers, bij de Javanen en Sumatranen; herten, buffels en runderen, bij verschillende Dajaksche stammen; palingen, bij de Makassaren en Boegineezen, de bewoners van de Philippijnen en bij de Amboneezen, enz. Het geloof in de verwantschap met, in de afstamming van, dieren is ook hier volkomen ernstig gemeend en in dien zin op te vatten, dat men werkelijk meent rechtstreeks uit de paring van dieren onderling, dan wel uit de paring van een dier met een mensch te zijn voortgekomen. Verscheidene verhalen kunnen worden aangevoerd, die bewijzen hoe gemeenzaam de inlander met dit

68 a Schultze, Der Fetischismus, blz. 196.

64 Zie voor het volgende uitvoeriger onze verhandeling: Het animisme bij de volken van den Indischen Archipel, blz. 68 vv.

64 a vereering van den krokodil komt ook bij den Dajakschen stam der OloNgadjoe's voor, niet echter als totem, op grond van de zielsverhuizing en het daaruit vonrtvloeiende begrip van verwantschap en afstamming, doch wel dewijl men in deze dieren de dienaren ziet van de djata's, eene categorie van goede geesten die de onderwereld bewonen (Zie: Animisme, blz. 215 vlg., en de daar angehaalde plaatsen). Ten onrechte wordt dus door Dr. Uhle, waar hij over de dierverwantschap spreekt (blz. 6), ook deze vereering bij de Olo-Ngadjoe's als voorbeeld aangehaald. 
begrip is 65. - Gelijk bekend is, behoeft de totem niet altijd een dier te zijn, doch kan evengoed eene plant wezen. Ook in den Indischen Archipel is het geloof in het ontstaan, het geboren worden van menschen uit planten zeer algemeen. Het is vooral uit bamboe en andere rietsoorten en uit rotan, dat personen heeten te voorschijn te zijn gekomen. In de literatuur en in de legenden vindt men talrijke verhalen van dien aard 66. - In het wezen der zaak komt het totemisme in den Indischen Archipel met dat van de Noord-Amerikaansche Indianen overeen. Toch wijkt het in een punt daarvan af. Zóóver is men namelijk hier niet gekomen, dat men zich naar de dieren of planten benoemt, die men als stamouders vereert of beschouwt. Alleen in de literatuur ontmoet men enkele voorbeelden waaruit blijkt, dat dit vroeger wel eens gedaan werd. Zoo treft men in de Bataksche verhalen nu en dan namen aan met den uitgang anan, welke uitgang bepaaldelijk gebruikt wordt, om de afstamming van dieren aan te geven, bij voorbeeld: Si-Lombuwanan, gevormd $\operatorname{van}$ lombu $=$ rund, als eigennaam van iemand die van een rund zijne afkomst afleidt, het rund dus tot totem heeft ${ }^{67}$. Zoo wordt in het Maleische werk "Hikajat radja-radja Pasei" van eene prinses verhaald, die uit een bëtung-bamboe was voortgekomen, en daarnaar Putèri-Bètung, dat is: "Prines Bamboe", heette $\mathbf{6 8}^{\mathbf{8}}$, terwijl in de legenden van de Alfoeren der Minahasa gesproken wordt van eene Prinses Uweranden, dat is: "Prinses Rotan", dus genoemd dewijl zij uit een rotanstruik gesproten was ${ }^{68^{a}}$. Ook stamnamen, aan dieren of planten ontleend, wijzen soms op het totemisme. Van de Bataks vinden wij onder anderen vermeld, dat elke stam of marga een dier (tijger, panter, kat, hond, geit, wilde tortel, enz.) heeft, dat aan de leden van den stam heilig is, omdat men meent daarvan af te stammen. In zeer enkele gevallen nu draagt de marga of stam ook den naam van dat dier. Zoo heet de marga, die den tijger tot totem heeft,

65 Zie: Animisme, blz. 73, noot 3.

60 Zie: Animisme, blz. 75 , noot 2. De daar gegeven voorbeelden kunnen met tal van andere vermeerderd worden.

${ }^{67}$ Zie: Van der Tuuk, Bataksch woordenboek, i. v. anan.

6s Hikajat radja-radja Pasei (ed. Dulaurier), blz. 1-2.

68a Boddé, Prinses Uweranden, Mededeel. v. w. h. Ned. Zend. Gen., dl. XXVIII, blz. 107 vlg. - Letterlijk beduidt de naam "Prinses Bindrotan". Het woord is toch samengesteld uit uwe = rotan en randen, dat, zooals Prof. Kern ons opmerkte, beantwoordt aan het Bisayasche dandan $=$ kabel, touw of koord van rotan of slingerplanten, zoodat uweranden beteekent: rotan die tot koord of touw dient, dat is dus: bindrotan. 
Babijat, dat is: tijger 69. Op die wijze zijn waarschijnlijk ook enkele stamnamen bij de Alfoeren van de Minahasa te verklaren, bij voorbeeld: Tou'm-bulu, dat is: menschen (afkomstig) van den bamboe, Tou'n-tewoh $=$ menschen (afkomstig) van den tewoh (eene rietsoort), Tou'm-pakěwa en Tou'm-basian = menschen (afkomstig) van den pakěroa en van den wasian (twee soorten van boomen), enz. $\mathbf{7 0}$.

$\mathrm{Na}$ het voorgaande kan ons de beteekenis van de dierenfiguren bij de Papoewas van de Geelvinksbaai duidelijk zijn. Het laat zich toch hooren, dat waar bij de vereering der afgestorvenen van beelden gebruik gemaakt wordt, men er licht toe komen zal, de voorvaderen, die zich in bepaalde dieren belichaamd hebben, ook in de gedaante van die dieren voor te stellen. Zoo deelt Dr. Riedel mede, dat de Aroeneezen krokodillen en haaien als hunne voorouders beschouwen en daarom de beelden van deze dieren in hunne woningen bewaren $\mathbf{7 1}$. Van denzelfden schrijver vernemen wij ook, dat de bewoners van de Ambonsche eilanden onder anderen het varken tot totem hebben 72. Het is zeker daarom dat, volgens Valentijn, voorheen in het dorp Ema als afgod het beeld van een varken aangebeden werd $\mathbf{7 3}$. Omtrent de Kalangs op Java, die, gelijk bekend is, hunne afkomst van een hond afleiden, wordt medegedeeld, dat zij houten figuren in de gedaante van dit dier vereeren ${ }^{\mathbf{7 4}}$. Doch vooral hebben wij hier te wijzen op de Papoewas van de Dorei-baai. Aan den zoogenaamden rumslam of rumsram, den tempel gewijd aan den dienst der voorouders, die hier gevonden. werd, waren ook tal van af beeldingen van slangen, visschen en krokodillen aanwezig, die ieder een bijzonderen naam droegen, en, volgens de inlanders, afgebeeld waren ter nagedachtenis van enkele hunner voorvaderen, welke van deze dieren afkomstig zouden zijn 75. Hieruit is nu dadelijk de conclusie te trekken, dat de dierenfiguren bịj de Papoewas van de Geelvinksbaai, aan voorwerpen van

60 Neumann, Het Pane- en Bila-Stroomgebied, Tijdschr. v. h. Nederl. Aardrijksk. Genootsch., 2e serie, dl. IV (Afd. Meer uitgebreide artikelen), blz. 8-9.

70 Deze verklaring van de stamnamen bij de Alfoeren der Minahasa uit het totemisme, komt ons eenvoudiger en natuurlijker voor dan die, welke onder anderen door den Heer Graafland, De Minahasa, dl. I, blz. 199 vlg., daarvan gegeven wordt.

71 Riedel, De sluik- en kroesharige rassen tusschen Selebes en Papua, blz. 253.

72 Riedel, O. c., blz. 32. - Ook op Timorlaoet behoort het varken tot de dieren, warin zich de zielen der afgestorvenen belichamen (Riedel, blz. 281).

73 Valentijn, dl. III, 1, blz. 5 en 52.

74 Ketjen, De Kalangers, Tijdschr. v. Ind. T. L. en Vk., dl. XXIV, blz. 427.

75 Nieuw-Guinea, ethnographisch en natuurkundig onderzocht en beschreven, ble. 155 . 
huishoudelijk gebruik voorkomende, eveneens totems voorstellen. Zooeven maakten wij onder anderen gewag van een hoofdsteunsel, dat een hond heet voor te stellen, doch vermoedelijk wel een cuscus is. $\mathrm{Nu}$ vinden wij den cuscus als een dier, waarin de afgestorvenen zich belichamen, onder anderen van Timorlaoet opgegeven 76. Het kan dus zijn dat ook bij de Papoewas van de Geelvinksbaai de cuscus een totem is. In allen gevalle wordt elke twijfel omtrent de godsdienstige beteekenis van het voorwerp opgeheven door de mededeeling van Dr. Meyer (blz. 7), dat het denzelfden dienst bewijst als een korwar, dat is met zoovele woorden gezegd, dat het de voorstelling is van een afgestorvene en gebruikt wordt, wanneer men zich met hem in betrekking wil stellen.

Bestaat er dus geen twijfel dat de dierenfiguren, waar zij alleen voorkomen, totems voorstellen, ook waar zij met menschenfiguren gepaard gaan, schijnen zij dezelfde beteekenis te hebben. Spencer heeft reeds uit het totemisme het geloof in, en de aanbidding van, hetgeen hij noemt "compound monsters - impossible hybrid animals, and forms that are half human, half brutal" trachten te verklaren. "If even", zegt hij, "we admit that some illusion may have suggested the belief in a creature half man, half fish, we cannot thus explain the prevalence among Eastern races of idols rapresenting birdheaded men, men having their legs replaced by the legs of a cock, and men with the heads of elephants". In overeenstemming met zijne theorie omtrent het ontstaan van het totemisme, is de verklaring, die Spencer van deze zaak geeft, geheel euhemeristisch. "When", aldus redeneert hij, "when tradition preserves both lines of ancestry when a chief, nicknamed the Wolf, carries away from an adjacent tribe a wife who is remembered either under the animal name of her tribe, or as a woman; it will happen that if a son distinguishes himself, the remembrance of him among his descendants will be that he was born of a wolf and some other animal, or of a wolf and a woman. Misinterpretation will entail belief in a creature uniting the attributes of the two; and if the tribe grows into a society, representations of such a creature will become objects of worship". Daarom behoeven wij ons niet te verwonderen "at finding among the Egyptians the goddess Pasht represented as a woman with a lion's head, and the god Month as a man with the head of a hawk. The Babylonian gods - one having the form of a man with an eagle's tail,

${ }^{76}$ Riedel, De sluik- en kroesharige rassen tusschen Selebes en Papua, blz. 281. 
and another uniting a human bust to a fish's body - no longer appear such unaccountable conceptions. We get feasible explanations, too, of sculptures representing sphinxes, winged human-headed bulls, etc.; as well as of the stories about centaurs, satyrs, and the rest" $\mathbf{7 7}$. Hoewel wij Spencer's redeneering niet in allen deele voor juist houden en vooral hem niet kunnen volgen, waar hij zoozeer in den wansmaak van het oude euhemerisme vervalt, moeten wij toch erkennen, dat hij onzes inziens in zooverre gelijk heeft, dat de gecombineerde menschen- en dierenfiguren in sommige gevallen, dat is waar zij dienst doen bij de vereering der afgestorvenen, werkelijk uit het totemisme moeten worden verklaard. Zoo ook bij de Papoewas van de Geelvinksbaai. Wij zijn het dan ook geheel eens met Dr. Uhle, als deze meent, dat "die vereinigte Darstellung der Thiere und Menschen wesentlich den Sinn hatte, eine Thierverwandtschaft des Menschen zu bezeichnen; man ehrte darin das Thier mit, von dem seine Existenz unzertrennlich gedacht wurde" (blz. 6). De gecombineerde figuren stellen dus, met één woord gezegd, de afgestorvenen en hunne totems voor. Werkelijk zijn de dieren, welke in die figuren voorkomen, krokodillen, slangen, visschen, hagedissen of leguanen, enz., juist die, welke het meest als totem worden vereerd.

$\mathrm{Bij}$ de algemeene verspreiding van het totemisme is er voor ons geen enkele reden om aan te nemen, dat deze instelling bij de Papoewas van de Geelvinksbaai niet inheemsch, doch door hen uit den Indischen Archipel ontleend is, gelijk Dr. Uhle wil. Waar de vereering der afgestorvenen naast de leer der zielsverhuizing bestaat, $\mathrm{kan}$, als een uitvloeisel daarvan, het totemisme bijna niet anders dan verwacht worden. Uit het feit dat het geloof in de verwantschap met, in de afstamming van dieren zoozeer zijne uitdrukking gevonden heeft in de beelden, die van de afgestorvenen gemaakt worden, moet men wel het besluit trekken, dat dit geloof bij de Papoewas meer in het volksbewustzijn is doorgedrongen dan bij de Westelijker wonende stammen van den Archipel. Wel is het niet geheel juist wat Uhle zegt, dat bij deze laatsten dierenfiguren "an den Ahnenbildern überhaupt noch nicht bestätigt sind" (blz. 4), doch zijn zij zeker uiterst zeldzaam. Een interessant voorbeeld ontmoeten wij echter op Timorlaoet. In het werk van den Heer Forbes vinden wij namelijk een beeld van eenen afgestorvene, hetwelk in zijne

77 Spencer, The origin of animal-worship, Essays: scientific, political, and speculative, dl. III, blz. 114-115. 
hauden eene schildpad heeft, die het zich tegen de borst drukt $\mathbf{7 8}$. Dat deze voorstelling met het totemisme samenhangt, is niet twijfelachtig. De schildpad behoort toch hier tot de dieren, waarin zich, volgens Dr. Riedel, de zielen der afgestorvenen belichamen 79.

Ten slotte willen wij hier nog eenige oogenblikken stilstaan bij hetgeen Dr. Uhle over de "Nackenschemel" zegt, de houten hoofdsteunsels, waarvan door ons hierboven reeds terloops een paar malen gewag gemaakt werd.

Het gebruik van houten hoofdsteunsels kwam, gelijk bekend is, ook bij de oude Egyptenaren voor. Het toestel, waarvan zij zich bedienden, bestond uit een halvemaanvormigen beugel bevestigd aan een voetstuk. "L'usage", zegt onder anderen Hamy, "de ces supports, si anciennement et si largement répandu dans l'ancienne Egypte, est encore aujourd'hui caractéristique des populations chamitiques ou éthiopiennes. Caillaud, dans son célèbre Voyage à Méroé rencontra, non sans étonnement, à Chendi des chevets de bois tout semblables à ceux qu'il venait de trouver à Thèbes " "servant

78 Forbes, A naturalist's wanderings in the Eastern Archipelago, blz. 327. Het beeld wordt, evenals dat bedoeld in noot 30 hierboven, door Forbes duadilah genoemd. "The Tenimber islanders", aldus deelt hij mede, "recognise some supreme existence whom they call Duadilah, of whom there is an image in their houses, over the principal seat, or dodokan, facing the entrance, with at its side a platter, or bilaan, on which a little food and drink is placed whenever they themselves eat" (Forbes, O. c., blz. 326). Dr. Riedel heeft echter, in zijne critiek van de mededeelingen van Forbes (Tijdschr. v. h. Nederl. Aardr. Gen., 2e serie, dl. I, blz 721 vv.), de opmerking gemaakt, dat de beelden, die de Timorlaoet-eilanders in hunne woningen bewaren, geene voorstellingen zijn van Duadilah (moet zijn Duadilaa), doch van de zielen der afgestorvenen, de matmate's of nitu's. Het wezen toch, dat onder den naam Duadilaa $=$ groote heer vereerd wordt, is hetzelfde als Ublera, elders Uplero, de Heer Zon, hier reeds min of meer de Zonneheer of Heer van de Zon. Van deze godheid worden wel beelden gemaakt, doch dezen bevinden zich niet in de woonhuizen, maar zijn in het midden van het dorp opgesteld (Zie hierover ook onze verhandeling: Het animisme bij de volken van den Indischen Arohipel, blz. 150 vlg.).

79 Riedel, De sluik- en kroesharige rassen tusschen Selebes en Papua, blz. 281. In het Ethnographisch Museum alhier bevindt zich een beeld uit den Indischen Archipel, dat groote overeenkomst vertoont met dat, waarvan Forbes in zijn werk eene teekening geeft. In plaats van de schildpad tegen de borst te drukken, houdt het echter het dier met de beide uitgestrekte handen voor het lichaam, op dezelfde wijze als de korwar's dit met het voorwerp doen, dat zij bij wijze van balustrade voor zich hebben. De juiste plaats van herkomst van het beeld is niet bekend. Daar het echter stellig niet van Nieuw-Guinea is, gelooven wij dat het op Timorlaoet of althans in het Zuiden van de Molukken tehuis behoort. 
d'oreiller aux momies"" ". Les nègres du Nil Blanc utilisent dans le même but un petit meuble assez différent, qui cumule les fonctions d'appuie-tête et de tabouret; mais dans la vallée du Nil Bleu, à Sennaar, par exemple, c'est le vrai chevet égyptien que l'on voit partout employé. Les Abyssins n'en connaissent point d'autre et il est d'usage constant chez toutes les tribus du Comal. Le chevet a même suivi les Chamites dans leurs invasions au milieu des tribus Bantous. Le Révérend Duff Macdonald l'a trouvé dans le bassin du Nyassa et $M$. Couret, qui accompagnait à titre de comptable, la mission d'exploration de $\mathbf{M}$. d'Andrada en a rapporté au Musée du Trocadero un très remarquable exemplaire recueilli dans la vallée du Chiré.... Le chevet est donc essentiellement chamitique, ou si l'on aime mieux, éthiopien" 80. Verder is het gebruik van houten hoofdsteunsels ook bekend in Japan en China. "Die japanischen Nackenschemel ", deelt Uhle mede, "sind kleine glatte Holzgestelle mit Schubkästchen und einem Kissen oben auf, im südlichen Japan kleine viereckige Holzplatten ohne Kissen" (blz. 8). In China bedient men zich van een "planchette montée sur quatre bâtonnets un peu obliques" 81. Daarnaast is echter nog een ander hoofdsteunsel hier in gebruik. "Mattresses or feather beds are not used", zegt Wells Williams, "and the pillow is a hard square frame of rattan or bamboo" $\mathbf{8 2}$.

Bij de volken van het Maleisch-Polynesische ras komen houten hoofdsteunsels in de eerste plaats voor bij de Papoewas van de Geelvinksbaai; doch verder is het bestaan daarvan nog geconstateerd bij de bewoners van het Arfak-gebergte en van de Humboldtsbaai, en bij de stammen van de Zuidwest- en de Zuidoostkust; buiten Nieuw-Guinea, in Micronesië, op het eiland Ratak, in Melanesië, onder anderen op de Fidji- en de Salomo-eilanden en op de NieuwHebriden, verder in Polynesië, op Samoa, Tonga en Tahiti. De vormen van deze hoofdsteunsels zijn zeer verschillend. Op Ratak gebruikte

80 Hamy, Note sur les chevets des anciens Egyptiens et sur les affinités ethnographiques que manifeste leur emploi, opgenomen in de "Etudes archéologiques, linguistiques et historiques, dédiées à Mr. le Dr. C. Leemans, à l'occasion du cinquantième anniversaire de sa nomination aux fonctions de Directeur du Musée archéologique des Pays-Bas" (Leiłe, E. J. Brill, 1885), blz. 32 vv.

si Hamy, O. c., blz. 34, noot 2.

s2 Wells Williams, The Middle Kingdom, dl. II, blz. 8-9. - Een bamboezen hoofdsteunsel uit China van eenigszins anderen vorm vindt men onder anderen afgebeeld bij: Schröter, Der Bambus und seine Bedeutung als Nutzpflanze, fig. 11 van de plaat. 
men daarvoor "einen etwas ausgehöhlten Holzklotz" 83, en op Tahiti een toestel "resembling a short low stool, nine inches or a foot in length, and four or five inches high; the upper side was curved, to admit the head; the whole pillow is cut out of a single piece" 84. Van Samoa lezen wij: "The pillow is a piece of thick bamboo, three inches in diameter, three to five feet long, and raised three inches from the mat by short wooden feet" 85. Ook op Tonga en Fidji bestaat het toestel dikwijls uit een stuk hout of bamboe, dat aan een voetstuk is bevestigd 86. De hoofdsteunsels van Nieuw-Guinea, bepaaldelijk die van de Geelvinksbaai, zijn ontegenzeggelijk het kunstigst. Het gedeelte, waarop de nek rust, is soms plat, soms gebogen, eene enkele maal zelfs bijna halfcirkelvormig, gelijk onder anderen bij de twee voorwerpen door Uhle afgebeeld op Plaat VII fig. 6 en 7, die daardoor, meer dan de anderen, eene groote overeenkomst vertoonen met de Egyptische hoofdsteunsels. Zooals wij hierboven gezien hebben, is het voetstuk met af beeldingen van menschen en dieren en met ander snijwerk versierd, en bestaat zelfs soms het geheele voorwerp uit een enkel dierenfiguur.

Op de eilanden ten Westen van Nieuw-Guinea zou, volgens Uhle, het gebruik van den "Nackenschemel" niet voorkomen. "Doch ", gaat hij voort, "haben die Malaien des Ostindischen Archipels auch keine flachen Kopf kissen wie wir, sondern schmälere und höhere, welche den Schemeln darum ähnlicher sind.... Der härtere Schemel könnte bei den Malaien von den weicheren Kissen verdrängt worden sein, wie in Japan ein gepolstertes Kissen zum Schemel hinzutrat " (blz. 8). Hij wijst er onder anderen op, hoe, volgens Dr. Riedel, de stammen van Centraal-Celebes heden ten dage nog "hoofdkussens van hout met iwo of boombast omwikkeld " gebruiken 87. Dit is echter niet het eenige voorbeeld. Dr. Uhle had nog meer volken uit den Indischen Archipel kunnen opnoemen, die een toestel van hout of iets dergelijks als hoofsteunsel bij het slapen bezigen. Zoo zegt de zendeling Sundermann, sprekende van het huisraad der

8s Waitz, Anthropologie der Naturvölker, dl. V, 2, blz. 88.

84 Ellis, Polynesian researches, dl. I, blz. 188-189, waar men ook zulk een hoofdsteunsel afgebeeld ziet.

${ }^{85}$ Turner, Samoa, blz. 15̌6. Zie ook: Schmeltz und Krause, Die ethnographisehanthropologisehe Abtheilung des Museum Godeffroy in Hamburg, blz. 218.

86 Schmeltz und Krause, O. c., blz. 185 en 196.

s7 Riedel, De volksstammen van Centraal-Celebes, Bijdragen tot de T. L. en Vk. v. Nederl. Indië, 5e volgreeks, dl, I, blz. 81. 
Niasers: "Einige Matten dienen um darauf zu schlafen und sich damit zuzudecken, ein Klotz als Kopfkissen " 8 . Van de Zee-Dajaks van Sarawak lezen wij, dat zij " rarely sit cross-legged upon the ground like the Malays, but have each a small block of wood about three inches in thickness, which they use as a seat by day and a pillow by night " 89. Ook in de Zuidooster-Afdeeling van Borneo komt het gebruik van houten hoofdsteunsels voor. Dit blijkt onder anderen uit het model van eene woning der Olo-Ot-Danoem van het midden stroomgebied der Barito, in het bezit van het Ethnographisch Museum alhier. In elk vertrekje, dat tot slaapplaats dient, is op den vloer eene mat uitgespreid met een langwerpig blok hout, waarvan de randen aan den bovenkant zijn afgerond, aan het hoofdeneind. Dit laatste wordt in de, bij het model behoorende, nota van toelichting, samengesteld door den controleur W. E. M. S. Aernout, omschreven als "een hoofdkussen, karuk, van zacht hout vervaardigd ". In de Molukken worden bij de Alfoeren van Boeroe dikwijls geene kussens gebruikt, " doch blokken hout, waarvan de randen eenigszins afgerond zijn" 90. Verder vermeldt Forbes van de bewoners van Timorlaoet, dat zij bij het slapen het hootd laten rusten " on a piece of squared bamboo with rounded edges, exactly similar to the Chinese pillow " 91. Op de Kleine Soenda-eilanden zijn het de Dou-Donggo

88 Sundermann, Die Insel Nias, Allgemeine Missions-Zeitschrift, dl. XI, blz. 353.

${ }^{89}$ Low, Sarawak, blz. 172.

${ }^{90}$ Zie onze: Bijdrage tot de kennis der Alfoeren van het eiland Boeroe, blz. 35. Zulk een houten hoofdsteunsel heet karnulu. Dit woord, dat ook in de zoogenaamde bahasa-tanah of landtaal der Ambonsche eilanden voorkomt als kananuru, karanulu, karnuru, karanuru (Van Hoëvell, Iets over de vijf voornaamste dialecten der Ambonsche landtaal, Bijdragen tot de T. L. en Vk. v. Nederl. Indië, 4e volgr., dl. I, blz. 81), beantwoordt aan het Javaansche karang-ulu, krômô-inggil van bantal $=$ kussen. Ook in het Maleisch en in het Bataksch wordt het gevonden, onder de, zeker meer oorspronkelijke, vormen van kalang-ulı en halang-ulu, terwijl het in het Dajaksch evenmin ontbreekt, waar wij het in het Katingansch aantreffen als kalang-olon (Tiedtke, Woordenlijst der Sampitsche en Katingansche taal, Verhandelingen v. h. Bat. Gen. v. K. en W., dl. XXXVI, blz. 13, i. v. bantal). Mag men nu uit het feit dat het voorwerp, hetwelk met dien naam wordt aangeduid, bij de Alfoeren van Boeroe van hout is, de conclusie trekken, dat dit voorheen ook bij de andere stammen het geval is geweest? Het zou gewaagd zijn deze vraag, zonder nadere gegevens, bevestigend te beantwoorden, te meer daar de benaming-zelve niets aanwijst. Gelijk men weet, is $u b u=$ hoofd, terwijl het Maleische kalang (ook wel galang), het Bataksche halang, "stut, steunsel" beduidt, zoodat kalang-ulu en halang-ulu, evenals het Javaansche karang-ulu en de daaraan beantwoordende vormen in de Molukken, zonder meer "hoofdsteunsel, hoofdstut" beteekenen.

${ }^{91}$ Forbes, A naturalist's wanderings in the Eastern Archipelago, blz. 318. 
van Oost-Soembawa en de Soembaneezen van wie gezegd wordt, dat zij een stuk hout als hoofdkussen bezigen ${ }^{92}$, terwijl de Savoeneezen zich daartoe bedienen van een, uit de bladeren van den lontarpalm gevlochten, blokvormig voorwerp, niet ongelijk waarschijnlijk aan het bamboezen hoofdsteunsel van de bewoners der Timorlaoet-eilanden 93. Aan deze gegevens, uit geschreven berichten geput, kunnen wij nog de mededeeling toevoegen, ons mondeling door Dr. Riedel verstrekt, dat ook op Aroe, Kei, Timorlaoet, Timor en meer plaatsen, houten hoofdkussens van eenvoudige bewerking, bestaande uit een blok dat aan het bovenvlak holrond of concaaf is gemaakt, nog heden ten dage in gebruik zijn.

Uit het voorgaande ziet men, dat houten hoofdsteunsels bij verschillende stammen in den Indischen Archipel voorkomen 94, zoodat het zeker niet gewaagd is met Dr. Uhle te onderstellen, dat zij vroeger eene grootere verspreiding hebben gehad, en eerst later, bij de Javanen, Maleiers en. de andere meer beschaafde volken, door de gewone kussens verdrongen zijn.

Onze aanteekeningen zijn hiermede ten einde. Men zal misschien zeggen, dat wij te weinig over het werk-zelf gesproken, en meer een opstel naar aanleiding daarvan, dan wel eene verhandeling daarover geschreven hebben. Maar kan het onze schuld heeten, dat de arbeid van Dr. Uhle zooveel te denken geeft? Want "anregend" is het boek in de hoogste mate en buitengewoon geschikt, tot verdere

92 Zollinger, Verslag van eene reis naar Bima en Soembawa, blz. 128; Roos, Bijdrage tot de kennis van taal, land en volk van het eiland Soemba, Verhandelingen v. h. Bat. Gen. v. K. en W., dl. XXXVI, blz. 20.

9s Zie: Catalogus van voorwerpen, verzameld in het Zendelinghuis van het Nederlandsche Zendelinggenootschap, Mededeel. v. w. h. Ned. Zend. Gen., dl. XXI, blz. 199. Op de daarbij behoorende Plaat II fig. 4, vindt men zulk een hoofdkussen afgebeeld. Zie ook: Teffer, De Savoe-eilanden, in hetzelfde tijdschrift, dl. XIX, blz. 231. - In het Javaansch heeft men nog, als krômô-inggil benamiñg van kussen, kadjang-sirah. $\mathrm{Nu}$ is sirah $=$ hoofd, terwijl kadjang eene dialectische uitspraak kan zijn van karang, zoodat kadjang-sirah geheel beantwoordt aan karang-ulu (zie noot 90 boven). Doch kadjang beteekent ook "vlechtwerk van palmblaleren", zoodat kadjang-sirah evenzeer te vertalen is door "vlechtwerk van of voor het hoofd", waaruit zou kumnen volgen, dat de Javanen zich voorheen bij het slapen van een dergelijk voorwerp hebben bediend als nu nog bij de Savoeneezen in gebruik is.

94 Volgens Hamy (O. c., blz. 34), gebruiken ook de, aan de stammen van den Indischen Archipel zoo nauw verwante, bewoners van Madagascar als hoofdsteunsel "une bûche de bois" of "un coussinet de joncs tressés, rembourré de coton". Hamy geeft echter hier zijne bronnen niet op. 
onderzoekingen aan te sporen, door de vele, niet zelden nieuwe en scherpzinnige opmerkingen, door den schrijver daarin gemaakt, hoe bestrijdbaar enkelen daarvan, bij voorbeeld die welke betrekking hebben op zijne stelling omtrent de niet-oorspronkelijkheid van de cultuur der Papoewas, wezen mogen. De ethnologen kunnen dus Dr. Uhle niet anders dan dankbaar zijn voor hetgeen hịj gegeven heeft. $W_{\text {ij }}$ Hollanders moeten hem bovendien erkentelijk wezen, dat hij, door zijn uitmuntend werk, de kennis van een, door ons zoo verwaarloosd, deel onzer bezittingen eene goede schrede vooruitgebracht heeft.

Leiden, Augustus 1887. 